\title{
Joyce's Ulysses, a Freudian and Schopenhauerian Reading
}

\author{
Stephen Rowntree, B.A. (York)
}

\author{
A thesis submitted to \\ The Faculty of Graduate Studies and research \\ in partial fulfillment of \\ the requirements for the degree of \\ Master of Philosophy \\ Department of Philosophy \\ Carleton University \\ Ottawa, Ontario, Canada \\ May, 2006
}

(C) Stephen Rowntree, 2006 


$\begin{array}{ll}\begin{array}{l}\text { Library and } \\ \text { Archives Canada }\end{array} & \begin{array}{l}\text { Bibliothèque et } \\ \text { Archives Canada }\end{array} \\ \begin{array}{l}\text { Published Heritage } \\ \text { Branch }\end{array} & \begin{array}{l}\text { Direction du } \\ \text { Patrimoine de l'édition }\end{array} \\ \begin{array}{l}\text { 395 Wellington Street } \\ \text { Ottawa ON K1A ON4 }\end{array} & \begin{array}{l}\text { 395, rue Wellington } \\ \text { Ottawa ON K1A ON4 } \\ \text { Canada }\end{array}\end{array}$

Your file Votre référence ISBN: 978-0-494-18297-0 Our file Notre référence ISBN: 978-0-494-18297-0

NOTICE:

The author has granted a nonexclusive license allowing Library and Archives Canada to reproduce, publish, archive, preserve, conserve, communicate to the public by telecommunication or on the Internet, loan, distribute and sell theses worldwide, for commercial or noncommercial purposes, in microform, paper, electronic and/or any other formats.

The author retains copyright ownership and moral rights in this thesis. Neither the thesis nor substantial extracts from it may be printed or otherwise reproduced without the author's permission.
AVIS:

L'auteur a accordé une licence non exclusive permettant à la Bibliothèque et Archives Canada de reproduire, publier, archiver, sauvegarder, conserver, transmettre au public par télécommunication ou par l'Internet, prêter, distribuer et vendre des thèses partout dans le monde, à des fins commerciales ou autres, sur support microforme, papier, électronique et/ou autres formats.

L'auteur conserve la propriété du droit d'auteur et des droits moraux qui protège cette thèse. $\mathrm{Ni}$ la thèse ni des extraits substantiels de celle-ci ne doivent être imprimés ou autrement reproduits sans son autorisation.
In compliance with the Canadian

Privacy Act some supporting forms may have been removed from this thesis.

While these forms may be included in the document page count, their removal does not represent any loss of content from the thesis.
Conformément à la loi canadienne sur la protection de la vie privée, quelques formulaires secondaires ont été enlevés de cette thèse.

Bien que ces formulaires aient inclus dans la pagination, il n'y aura aucun contenu manquant.

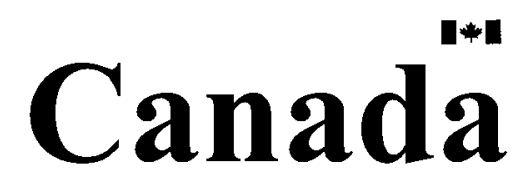




\section{Contents}

Abstract........................................................................

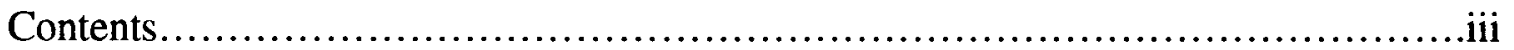

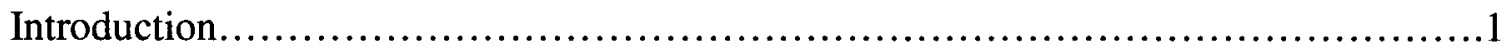

Chapter 1: Schopenhauer's Concept of the will, Willessness and Disinterestedness.......2

Chapter 2: Freud's Concepts of the Unconscious, Free Association, Creativity and

Dreams.........................................................26

Chapter 3: Schopenhauer and Joyce's Ulysses.....................................43

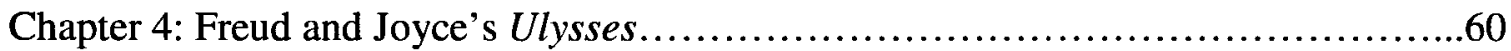

Conclusion................................................................ 77

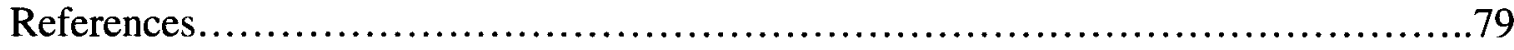




\section{Abstract}

The objective of this thesis is to look at Joyce's novel Ulysses from the perspective of Schopenhauer and Freud, to see what they have to offer to a reading of the novel. Chapter

One outlines Schopenhauer's notion of the will and willessness, the concept of disinterestedness, and his theories of sexuality and aesthetics. Chapter Two outlines Freud's notion of creativity, drawn principally from his work 'Creative Writers and Daydreaming', and his notions of the unconscious, free association, sublimation and dreams. Chapters Three and Four apply Schopenhauer's and Freud's concepts to Ulysses.

The objective is to see where and how Schopenhauer's and Freud's theories might shed new light on Joyce's work. I hope to show how the cessation of willful activity and disinterestedness of which Schopenhauer wrote are common to the characters' narrative voices in Ulysses, in particular that they are disinterested in their own interests. With regard to Freud, I hope to show how his concepts of the unconscious, primary process and dreams can help illuminate Joyce's characters, and that there are both interesting similarities and important differences between Freud's free association and Joyce's stream of consciousness. 
Ulysses, on the technical side, is an immense exercise in style, an orgy of 'apeishness,' decidedly 'sedulous'. It is an encyclopaedia of English literary technique, as well as a general-knowledge paper. The schoolmaster in Joyce is in great evidence throughout its pages. (Lewis, 1957, p.76)

Wyndham Lewis, writer, painter and critic, wrote these lines about Joyce in 1927 in his book Time and Western Man. Joyce, the master language manipulator, the evervigilant stylist and intellectual, delivered to the twentieth century reader a book of such extraordinary richness and literary buffoonery that today, some eighty years past, it still confounds and challenges many a reader. Lewis states,

The method that underlies Ulysses is known as the 'telling from the inside.' As that description denotes, it is psychological. Carried out in the particular manner used in Ulysses, it lands the reader inside an Aladdin's cave of incredible bric-abrac in which a dense mass of dead stuff is collected, from 1901 toothpaste, a bar or two of Sweet Rosie O'Grady, to pre-nordic architecture. An immense naturemorte is the result. This ensues from the method of confining the reader in a circumscribed psychological space into which several encyclopaedias have been emptied. (Ibid, p. 91)

Lewis appraisal of Joyce's Ulysses seems, even today, to challenge the contemporary notions of literary style and content. Joyce wrote Ulysses in a manner casting aside the trappings of traditional modern novel writing, the pleasantries and complacencies inherent in English literature, and in so doing introduced an unparalleled philosophy of fiction.

In this thesis I discuss Schopenhauer's notion of will-lessness and disinterestedness and Freud's notions of free-association, the unconscious, repression and sublimation. In chapters three and four I see what these notions have to offer to a reading of Joyce's Ulysses. First I will survey Schopenhauer's philosophy of the 'will' drawing from it an idea of will-lessness and disinterestedness that can apply to a reading of Ulysses as an example of 'will-less' or 'disinterested' narrative. As dense and often 
impenetrable as Ulysses may appear at first reading, it seems to share some commonalties with Schopenhauer's notion of will-lessness. Both systems, one metaphysical the other fictional, work from within an open philosophical narrative that suspends the notion of a willful engagement with the world, relying on psychologicalism and inner-narrative. This is most evident in Joyce; however Schopenhauer can also be read to work from without, meaning from a suspended plane of narrative. By this I mean a suspension of the will that allows for creative apprehension and disinterestedness.

Secondly, I will look at Freud's notion of creativity, drawn primarily from the small work entitled, Creative Writers And Day-Dreaming, and his writings on metapsychology. Freud's writings on creativity, though somewhat unsatisfying, reinforce his notions of free-association, the unconscious, repression, sublimation, dreams and interpretation as instrumental to the creative endeavor. His notions of creativity as child's play and sublimation are sustainable examples of how creativity can be understood in psychoanalytic terms. Freud also emphasizes the importance of phantasies for creativity and how they play a key role in the construction of works of art such as Joyce's Ulysses.

In the third chapter I will employ Schopenhauer's notion of will-lessness and disinterestedness to a reading of Ulysses, paying close attention to the similarities between the two writers. In so doing I hope to show how Joyce's novel Ulysses can be read in a manner complementing and expanding upon Schopenhauer's notion of willlessness and disinterestedness. Even though Joyce wrote with great skill and discipline, plotting and furiously rewriting the narrative and story that was to become Ulysses, there is a free-play of narrative voice, or what I refer to as a monologic narrative, that plays 
throughout the novel. This, I suggest, can in some ways be attributed to a

Schopenhauerian notion of will-lessness and a disinterested narrative voice or voices.

In chapter four, which deals with Freud and Joyce, I will discuss the similarities between free-association, as represented in psychoanalysis, and stream-of-consciousness, a literary style used throughout Ulysses, to see how they both complement, and perhaps reinforce, the creative element in each other. I will also look at Freud's notion of dreams, the unconscious, childhood play and primitive thinking. There appear to be many connections and twinning between Freudian psychopathology and Joycean word play, and this chapter hopes to draw attention to this phenomenon.

\section{Chapter One, Schopenhauer}

In the World As Will and Representation, Schopenhauer outlines a notion of metaphysics that is non-relational, non-conceptual and concerned with an account of the body and the intellect apprehended as a whole. In this manner body and the intellect are indivisible, they represent a manner of knowing that apprehends the world through the body and the intellect of willing individuals coalesced as one. It is my contention that Schopenhauer, though he never mentions it, had a metaphysical notion of creativity that was couched in his idea of genius and imagination, drawn, I suggest, from this notion of a metaphysical agent that can apprehend and enjoin the aesthetic suspended from the activities of the will. This idea of will-less apprehension, specific to creativity, is the cornerstone of what will be refereed to as a 'disinterested' aesthetic activity. If we stretch the notions of 'genius' and 'imagination', as interplayed in Schopenhauer's metaphysics, 
we can arrive at a concept of creativity that can be applied to a reading of Joyce's Ulysses, and in so doing, draw interesting parallels between the two systems, one metaphysical the other fictional. First, we will look at Schopenhauer's notions of the will and representation and their relation to his entire philosophy; secondly, we will discuss his ideas on art and aesthetics and explain how they fit into his idea of reason and intellect.

In the World As Will And Representation Schopenhauer begins by explaining what he means by the words 'representation' and 'will'. Representation refers to all of the phenomena that we perceive in the world. The will represents the manner in which the individual interacts with the world of phenomena. The material objects which we, as knowing individuals experience, depend for their order and existence on the "knowing self'. The same world that I apprehended as representation must also be viewed under the aspect of what Schopenhauer refers to as the 'will'. Schopenhauer borrows from Kant's notion of transcendental idealism, suggesting that individual 'things' would cease to exist without the experiencing subject. Schopenhauer writes,

The world is entirely representation, and as such requires the knowing subject as the supporter of its existence. (Schopenhauer, 1969, p.30)

Subject and object play important roles in Schopenhauer's notion of the will and representation. Subject is that which knows or experiences, object is that which is known or experienced.

That which knows all things and is known by none is the subject. It is accordingly the supporter of the world, the universal condition of all that appears, of all objects, and it is always presupposed; for whatever exists, exists only for the subject. (Ibid. p.5) 
Whatever can be experienced as such exists only in relation to our experiencing it. Apprehension is the business, so to speak, of the intellect or understanding. When we act our body moves and our awareness of its movement is unlike our awareness of events that we apprehend. Janaway writes,

I am 'outside' other objects, or they are 'outside me-but my body is mine in an intimate way. This can be expressed by saying that other events are merely observed to happen, whereas movements of my body are expressions of my will. (Janaway, 1994, p.250)

In this manner Schopenhauer conceives of the act of the will and the action of body as one and the same. As such, the will is the moving force in agency; it determines and underlies what individual action is and how it is carried out. The act of willing, then, includes bodily manifestations, and the whole body is nothing more than the objectified will.

Every true, genuine, immediate act of the will is also and directly a manifestation of the body. (Ibid. p.110)

The will interacts and engages with the world and the representations drawn from those interactions. Interestingly enough however, this agency of the will cannot be truly considered 'free' in the sense of an exercising of 'free will', as it is constrained by an external and changeable experiential world. We say that a person acts on his or her "free will' when he or she is not hindered or restrained by something external to his or her will.

The action of the body is one single occurrence, which presents two aspects: the subject and the object. When we will, we are grounded in the world of objects. The subject of the will, then, is always bodily, and our bodily existence, according to Schopenhauer, is nothing more than willing. The will, according to Schopenhauer, is the 
'thing in itself', and as such accorded a fundamental role in apprehension. Schopenhauer insists that,

...only the will is the thing in itself...It is that which is, all representation, all object, is the phenomenal, the visibility, the objectivity. It is the innermost essence, the kernel, of every particular thing and also the whole. It appears in every blindly acting force of nature, and also in the deliberate conduct of man, and the great difference between the two concerns only the degree of the manifestation, not the inner nature of what is manifested. (Ibid. p.101)

The will is not something occupying space or time: it is simply the subjectimposed structure of the world of representation. The 'thing in itself' is what remains when the world as representation is thought away. (This idea of the 'thing in itself' will play a key role in the notion of creativity as a will-less activity). What we are conscious of is our own willing in action, not the objects of space and time themselves. Our knowledge reaches only as far as the phenomena of inner and outer experience. Schopenhauer contends that we cannot know the thing in itself; it is strictly unknown. Creativity, if understood as a will-less activity, may in fact override this notion of the unknowable, suggesting that when all willful activity is suspended and external reality and representations cease to impinge on cognitive activity, we are free to explore the 'inner' activities of creative thinking.

Schopenhauer's notion of sex is central to his concept of the will and willlessness. Sex is a willful act, one where the will is exercised and directed outside of the self. In this way sex, coition, is a directed or interested activity, one that has a purpose and a drive, the procreation and extension of the species. Schopenhauer felt that individuals were driven by their obsession with sex, and saw it as a means to an end, a directed activity. Sex is ever present in our minds, 
...the public secret which must never be distinctly mentioned anywhere, but is always and everywhere understood to be the main thing. (Schopenhauer, 1958, W2, p.571)

Sexual drive is antithetical to the notion of a will-less activity in that it is a driven and object-related, not a disinterested activity where the self is pulled away from the outside, the relational. Schopenhauer felt that sex was an almost all-consuming passion, one that has the tendency to interfere with our daily lives.

It is the ultimate goal of almost all human effort; it has an unfavourable influence on the most important affairs, interrupts every hour the most serious occupations. (Ibid. p.533)

Sex, or sexual drive, is purposeful, and as such a willful activity, an act of will. In contrast to disinterestedness, which is will-less and not driven by anything outside of itself, sex is a pointed example of willfulness. As we will see in chapter three, Schopenhauer's conception of sex serves as a good example of an interested or nondisinterested activity, one that engages with rather than disengages from the outside, the referential. "The occasion of the most vehement willing, the focus of the will, the sexual impulse..."(Ibid. p.637) This vehemence of the will, its drive for something outside of itself, is central to Schopenhauer's The World As Will And Representation. It is the willto-live, the impulse to self-preservation.

If the will-to-live exhibited itself merely as an impulse to self-preservation, that would be only an affirmation of the individual phenomenon for the span of time of its natural duration. The cares and troubles of such a life would not be great, and consequently existence would prove easy and cheerful. Since, on the contrary, the will wills life absolutely and for all time, it exhibits itself at the same time as sexual impulse which has an endless series of generations in view. This impulse does away with that unconcern, cheerfulness, and innocence that would accompany a merely individual existence, since it brings into consciousness 
unrest, uneasiness, and melancholy, and into the course of life misfortunes, cares and misery. (Ibid. p.568)

If, as Schopenhauer suggests, aesthetic apprehension is disinterested, then sex, or the sexual impulse, can never be the source of creative endeavor, as it is an act of will, and as such, directed or interested.

A will-less engagement does not require perception as a condition for knowing, or as in creativity, apprehension. This will-less, non-perceptual apprehension, then, is freed from the impinging representational field of cognition, whose requirement is a representation of the object or thing apprehended, allowing it access to a purely 'inner' mental activity. This divergence between 'willful' and 'will-less' mental activities supports the notion of creativity as a function of a cognitive apprehension that ceases to be influenced by the relational. In this manner, the suspension of the will is a key ingredient to creative activity, a notion that will be expanded upon later on in the essay. In this manner creativity may be the expression of an 'inner' apprehension that is possible only when these external impingements are removed.

A fundamental requirement of Schopenhauer's aesthetics is this condition of a suspension of the will: once an individual ceases to be constrained by the will, he or she is free to explore an apprehension of 'things' and objects that are not relational in context; suggesting that this position of unrestraint is conducive to the possibility of creative thought. To fully experience something aesthetically, an individual must suspend all his or her desires towards that object. This will-less apprehension supports Schopenhauer's claim that aesthetics exists on a plane outside the confines of the willing subject. If we accept this line of reasoning, keeping in mind the very notion of a 
'disinterested' agency that is free from constraint, we arrive at philosophical aesthetics of creativity that is free in the sense of a will-less freedom of thought, rather than a willful or directed one.

The willing subject directs his or her will towards a deficiency in the willing subject; in this manner the will strives towards the avoidance of suffering and the adoption of pleasure. Schopenhauer writes,

As such, it is called pain when it is contrary to the will, and gratification or pleasure when in accordance with the will. The gradations of the two are very different. (Ibid. p.101)

In this manner the individual experiences less satisfaction and more suffering in a world bound and determined by acts of will than in one unrestrained by willing. If the motivation and drive for aesthetic apprehension is some sort of pleasure, or as suggested, a suspension of willing, than Schopenhauer has to do away with this notion of striving and in its place erect a will-lessness that performs no such activity. The idea of a 'disinterested' aesthetics, which makes creative activity possible, suggests that if creativity is to have any positive value at all, it must be capable of producing some degree of pleasure or a cessation, even momentarily, of pain and suffering'. Otherwise, there would be very little motivation to create or be creative, even when pain or suffering is the subject of art and literature. Janaway suggests that,

The problem for aesthetics is how there can be any kind of pleasure other than that which is contained in this oscillation. (Janaway, 1994, p.285)

Would a will-less state leave room for real pleasure? In this will-less world there is no place for suffering or pleasure; the will as such is suspended; happiness and unhappiness have disappeared altogether. Although it is difficult to imagine a creative apprehension or act that is totally devoid of some form of pleasure or suffering. Perhaps 
Schopenhauer's will-less aesthetic includes pleasure, pain and suffering, but driven by an aesthetic drive rather than a willful drive. The usual kind of happiness and unhappiness depends on willing: the aesthetic kind depends on a total lack of willing; or perhaps a aesthetically-driven will-lessness that is particular to 'disinterestedness'; a pulling away from the everydayness and a drawing towards the aesthetic. According to Schopenhauer, a will-lessness-an experience in the absence of subjective desires and aims - will be one which distorts the world as little as possible. Indeed, aesthetic experience is desirable because it displays things as they are represented eternally. Schopenhauer believed that we could, in exceptional moments, gain access to a timeless reality that is not made up of individuals. Following Plato's notion of Ideals or forms, he claims that artists, and all individuals engaged in aesthetic experience, can experience this timeless reality of ideas. These Ideals represent 'the most adequate objectivity' of the thing in itself. Schopenhauer conceives of these timeless Ideas, and our apprehension of them, as the most objective knowledge of the world we can ever attain. (Like the Platonic Ideals, they exist independently of the subject.) Schopenhauer says,

We apprehend the world purely objectively, only when we no longer know that we belong to it. (Schopenhauer, 1966, p.368)

According to Schopenhauer, the individual of genius has two-thirds intellect and one third will, while the normal person is the opposite of this. The creative individual, or the genius, is capable of detaching his or her intellect from the will, and has the power to function autonomously. The most complete objectivity consists of the ability to remain in a state of pure apprehension; to be removed completely from the will. Schopenhauer writes, 
In other words, genius is the ability to leave entirely out of sight our own interests, our willing, and our aims, and consequently to discard entirely our own personality for a time, in order to remain pure knowing subject, the clear eye of the world; and this not merely for moments, but with the necessary continuity and conscious thought to enable us to repeat by deliberate art what has been apprehended. (Schopenhauer, 1969, pp.185-86)

According to Schopenhauer, genius has the ability to see the universals in the particular.

He also maintains that perceiving is not enough, imagination is also required.

Imagination is needed, in order to complete, arrange, amplify, fix, retain, and repeat at pleasure all significant pictures of life. (Ibid. p.379)

Schopenhauer sees the arts as an intense form of knowledge and a release from the pressures of living in general. Paintings depicting scenes from history or from Biblical stories are artistically significant to the extent that they express something universal about humankind. Poetry expresses the world; it portrays the diverse characters and actions of individuals in general. For Schopenhauer music represented a copy of the will itself.

Music does not express this or that particular and definite pleasure, this or that affliction, pain, sorrow, horror, gaiety, merriment, peace of mind, but joy, pain, sorrow, horror, gaiety, merriment, peace of mind themselves, to a certain extent in the abstract, their essential nature, without any accessories, and so also without motives for them. (Ibid. p.261)

In music we apprehend directly and non-conceptually the essential shape of emotions, without any content or representation of what the emotion is about.

Imagination has been rightly recognized as an essential element of genius; indeed, it has sometimes been regarded as identical with genius, but this is not correct. (Ibid. p.186)

The genius is constantly searching for new objects worthy of contemplation. The concept of imagination, extended in genius, plays an important role in creativity: it helps 
to define and express the aesthetic idea. It is this constant striving for ideas that gives genius its imaginative quality. The imagination, as with creativity, if understood as a 'disinterested' aesthetic activity, doing away with the urgency of the will, allows for a sense of curiosity that is not constrained by the agency of willing; and in so doing, suggests a free and uncontainable creative apprehension. I suggest that we can experience an artistic or creative realm that opens up through Schopenhauer's concepts of genius and imagination. When we have access to will-less activity, as is suggested through a 'disinterestedness' that overrides the constraints of the will, we are free to explore, through imagination and curiosity, our relationship with the world; an exploration that is both creative and imaginative. Schopenhauer's notions of genius and imaginationimagination being an apprehension of ideas and the object of those ideas, and the ability to imagine them differently from what they represent-represent a change in the way that the individual experiences the Idea, or form, of the aesthetic. The concept of imagination, in helping to clearly define the thing it itself, is integral to Schopenhauer's metaphysics.

On the notion of imagination, Schopenhauer suggests the following,

Therefore the man of genius requires imagination, in order to see in things not what nature has actually formed, but what she endeavored to form, yet did not bring about, because of the conflict of her forms with one another which was referred to in the previous book... Thus imagination extends the mental horizon of the genius beyond the objects that actually present themselves to his person, as regards both quality and quantity. For this reason, unusual strength of imagination is a companion, indeed a condition of genius. (Ibid. pp.186-87)

What Schopenhauer means by 'see' is confusing. Do we see these things in our mind's eye, or do we apprehend the object itself? What we apprehend is not necessarily what we see; they can be altogether different. In Schopenhauer's will-less realm 
individuals are removed from pleasure and suffering, and apprehend the 'things' through the faculties of genius and imagination. Again, how can we talk about the pleasure or beauty of a piece of art, without assigning to our apprehension of the object a pleasurable or unpleasurable response? If on the other hand creativity exists as a form of apprehension which does not take into consideration the pleasure or suffering of the artist or viewer, then aesthetics is limited and lacking any objectified expression. Creativity, then, has nothing whatsoever to do with the inherent beauty or pleasurable value placed on the object of apprehension. What Schopenhauer ends up with is,

Consequently a face's 'expression of genius' consists in the fact that a decided predominance of knowing over willing is visible in it, and hence that there is manifested in it a knowledge without a relation to a will, in other words, a pure knowing. (Ibid. p.188)

The notion of an activity of 'pure knowing' put forth by Schopenhauer in the quotation cited above implies that the complete cessation of the will is, as I have suggested, a condition for aesthetics, and more importantly, creativity and imagination founded on the notion of 'disinterestedness'.

The genius has a certain higher capacity for imagination and knowledge. The individual of genius and imagination, then, has the capacity to apprehend the form or Idea of pure knowledge without the impression left by the will. Schopenhauer writes,

Now according to our explanation, genius consists in the ability to know, independent of the principle of sufficient reason, not individual things which have their existence only in relation, but the Ideas of such things, and in the ability to be, in face of these, the correlative of the Idea, and hence no longer individual, but pure subject of knowing. (Ibid. p.194)

Schopenhauer suggests that our delight in painting, for example, resides in the objective correlation of this apprehension in pure will-less knowing. In this manner we 
see the beauty not of the object itself, but the Idea that is apprehended in the will-less apprehension of this Ideal. This Ideal, or idealization of the object, is not something changeable or mutable, but as it is, in-itself so to speak. By this I mean changeless, or more precisely, apprehensible as an idea or ideal of creativity.

We are capable of recognizing human beauty when we see it, but the artist apprehends beauty with such clearness and perspicuity that he or she shows beauty as it has never before been seen. The notion of beauty in aesthetic contemplation, as earlier discussed, is not something that can be easily explained if we are to remain consistent with the idea of a 'disinterested' creative activity.

Schopenhauer contends that the artist and the genius, in many ways the same, are capable of attaining a higher degree of apprehension than the ordinary individual attains. This apprehension deals with the Ideal, or Form of the thing apprehended. The form, or Idea of the object, is understood as an unchanging Idea of the object represented in phenomenal terms; we do not see the thing itself, but the representation of that thing.

Now according to Schopenhauer's notion of aesthetics, the artist sees the form, not the individual thing itself. An individual can be a good technician, yet remain relatively lacking in creativity capabilities. Creativity, like genius, arises from the capability of the artist, or genius, of being able to apprehend these Ideal forms. It would seem that the creative person is capable of touching upon an area of the mind, will-lessness, that allows for this 'disinterested' sense of awe and curiosity. It is true we all have a capacity to be creative; however, there are those individuals that have heightened creativity that expresses itself in the arts, poetry, sculpture, business, sciences, mothering, cooking, etc. 
Schopenhauer contended that the creative individual is capable of rendering the Ideal of the object, which we the viewer, see only through his or her eyes. The artist possesses the clarity to apprehend the Ideal of the phenomenon of the representation of nature. With nature constantly in a flux, the artist settles an image or object in the stillness of the Idea.

For to fix the fleeting world, which is forever transforming itself, in the enduring picture of particular events that nevertheless represent the whole, is an achievement of the art of painting by which it appears to bring time itself to a standstill, since it raises the individual to the Idea of its species. (Ibid. p.231)

According to Schopenhauer, artistic apprehension, which is the aim of the artist, is to be understood as the Idea in the Platonic sense. It is not the particular thing, the object of common apprehension (such as the appearance of a flower which may seem, on being experienced or perceived outwardly, to possess beauty or creative form but no Ideal or creative idealization as suggested earlier) but this Idea, which answers to the truth of creativity. Only the individual who has raised him or herself above all willing and all individuality, can apprehend this Idea. The apprehension of the Idea, according to Schopenhauer, is the true and only source of every genuine work of art.

In its powerful originality it is drawn only from life itself, from nature, from the world, and only by the genuine genius, or by him whose momentary inspiration reaches the point of genius. (Ibid. p.235)

The poet, for example, apprehends the Idea, 'the inner being of mankind outside all relation and all time'. The creative individual, like the person of genius, apprehends nature with heighten clarity. Schopenhauer says that this will-less contemplation draws us further away from the willing world of apprehension, and in doing so, gives us peace of mind which all men seek. The purpose of art, then, is the expression and presentation 
of these Ideas. "The (Platonic) Ideas are the adequate objectification of the will." (Ibid.p.257) The artist or genius, according to Schopenhauer, apprehends pleasure from the contemplation of these Ideals, which allow him or her to apprehend things outside the constraints of the will.

Does Schopenhauer's aesthetics and notion of creativity based on 'disinterestedness' and will-less apprehension have something of value to add to our understanding of creativity? I would have to say yes, certainly. Schopenhauer wished to encourage us to experience the world of objects outside the thing itself, yet as part of that thing or object. He accomplished this, I believe, through the notion of a will-less apprehension of aesthetic Ideas, or Ideals, that allow us to remain outside the object apprehended, while at the same time being connected through imagination and creative thought to the object or thing intimately. In this manner we are capable of transcending the thing in itself, and apprehending the idea of the thing, or Ideal, which is also the thing in itself, yet contingent on our free and will-less experience or apprehension of it. In this way he used will-lessness as a means to understanding the ideal of the thing apprehended in itself. He wanted to show us that we could use the will to apprehend the mundane world of representations, and a suspension of the will to understand the thing itself: the idea or notion of the aesthetic quality in things as we apprehend them outside the will. Schopenhauer uses this notion of will-lessness to make sense of objective knowledge, or apprehension of things apprehended without the use of the will, the representation of the thing, or object itself.

Schopenhauer struggled with the notion of a 'better consciousness' at the beginning of his philosophical system. He believed that there could be a will-less way to 
apprehend the idea of things freed from their empirical underpinnings. This accuracy was to be found in the cessation or suspension of the will, which gives the individual access to the creative agency or imaginative curiosity of things and objects in the world. This sense of curiosity, which is a key to our understanding of creativity and imagination, has no bounds or constraints. In his notion of the aesthetic as a way of apprehending things (ideas) beyond the acquisition of the will, he opened up a transcendent means to apprehending (we do not speak of understanding here, because we do not understand the aesthetic but simple apprehend or experience it) these things that have meaning outside of their representations. We cannot dispose of the idea of the thing or object as it is perceived and experienced outwardly, because it is through this representation that we have knowledge of things in general; and it is in this manner that we have 'thoughts' of things themselves. What Schopenhauer wanted to show us was that we could have ideas of things outside the perception of those things; we can apprehend the aesthetic of a thing outside the phenomena of the thing or idea itself. We understand or apprehend music as such, and we can appreciate it creatively through the will-less apprehension of it as a thing transcendent from representation.

We cannot accept Schopenhauer's notion of aesthetics without in turn embracing the idea of representation. Things are understood through their representation to us: they are understood as representational, as things that are apprehended through representation of the thing we perceive. It is here that we run into difficulties with the notion of the will-less state of apprehension and the idea of things as being representations of things we perceive and understand in the world in general. Things are represented to cognition as the thing in its temporal and spatial positions in the world of things themselves. They 
must adhere to this condition if we are to have an understanding of them at all. Representation is fundamental to cognition; we cannot be said to have an understanding of something outside its representation. It is here that Schopenhauer's idea of the will has its problems. The will, according to Schopenhauer, is transcendent or mystical; it does not take into consideration the apprehension of things in general. The notion of a willless state of apprehension, as Schopenhauer indicates in his idea of the aesthetic, is problematic in itself. What exactly do we understand as a state of will-lessness? How do we know when we are in a will-less state of apprehension? If we grant Schopenhauer his notion of will-lessness, we must in turn raise the question of mysticism.

A will-less aesthetic is not something apprehensible in perceptive terms. This will-lessness is a function not of perception, but rather of a transcendentalism that transcends the phenomena and apprehends the Ideal in itself. Grounding Schopenhauer's aesthetics in representational terms fails. We cannot accept will-lessness and representation; they cannot exist together. The representation of a thing requires that the will be present in its apprehension, according to Schopenhauer's philosophical system. He would have to reconcile his transcendentalism with representationalism, which he clearly does not. Where does this leave us with our notion of creativity? According to Schopenhauer, a will-less act is an act of creativity. Creativity, therefore, is will-less. If creativity is a will-less state of apprehension, like aesthetics, then we cannot have an empirical or perceptual notion of aesthetics, as it becomes something mystical and transcendent.

Having said this, however, it is possible to allay any mystery or inconsistencies in Schopenhauer's aesthetics without having to ascribe to it a form of mysticism. This 
notion of a 'disinterested' creative stance, or a will-less apprehension of Ideas, is key to an understanding of Schopenhauer's conception of creativity. As discussed earlier, the notion of a disengagement, or suspension of willful thought, allows the individual to access a realm of creative thought otherwise inapprehensible in a world of constant external activities and mutable relational phenomena. The artist is driven by a sense of curiosity that works free of the causal impingements suggested. This sense of curiosity found in disinterestedness does not depend on the outward relations of things and objects as such, but on the 'inner' drive to create something new, something that has no causal connection to the external world of ideas, or if it does, only incidentally. Creativity and imagination are, in this manner, gifts of free unrestrained thought, thought that is therefore will-less. As strange as it may seem, will-lessness is an expression of freedom in that it is not desirous of anything outside of the individual, nothing that is striven for or pleasure seeking, but rather an accession to unrestrictive thinking and apprehension of ideas and objects as they are in themselves.

Schopenhauer writes,

As soon as we objectively consider, i.e. contemplate the things of the world, then for the moment subjectivity and thus the source of all misery has vanished. We are free and the consciousness of the material world of the senses stands before us as something strange and foreign which no longer wears us down. Also we are no longer involved in considering the nexus of space, time and causality, but see the Platonic Idea of the object... This liberation from temporal consciousness leaves the better or eternal consciousness behind. (Ibid. p.50)

Apprehension detached from will allows for the transformation of the world into a spectacle that can be watched with 'disinterestedness'.

The pleasure of everything beautiful, the consolation afforded by art, the enthusiasm of the artist which enables him to forget the cares of life....all this is due to the fact that...the in-itself of life, the will, existence itself, is a constant 
suffering, and is partly woeful, partly fearful. The same thing, on the other hand, as representation alone, purely contemplated, or repeated through art, free from pain, presents us with a significant spectacle. (Ibid. p.267)

For Schopenhauer the aesthetic is accorded the highest possible philosophical ranking.

He believed that the contemplation of the aesthetic, being detached from the will, transforms the object viewed into a 'spectacle' that brings us closer to the 'objectification of the will' or the 'idea' itself.

Art and philosophy express the ability to remain in a state of 'pure' apprehension, to lose oneself in apprehension and to be removed from the presence of the will. The artist or writer is released from the outside-ness of the world of representation, and as such free to explore and create from a sense of curiosity which is not determinate on the object, but rather the idea or Ideal in memory, or the acquisition of newly formed ideas and Ideals drawn from these very explorations. In this manner, as so far suggested, it is this 'disinterest' that sets aesthetic apprehension apart from the constraints of the will.

Can we apply Schopenhauer's notion of aesthetics and will-lessness as means to understanding the creativity behind a given work of art? For example, the sixteenth century painter Caravaggio changed the way subject and composition were represented in painting. He used prostitutes and street people as models for his paintings, and created subjects that were outside the accepted canons of sixteenth century religious painting. Caravaggio took the subjects and objects that surrounded him and reworked them into representations of religiosity that were to introduce a new theme into the subject in sixteenth century painting. He found the mundane and the mystical to be one in the same, and through his work discovered the true nature of religious painting, one that was not founded in the transcendent, but rather in the common or secularity of the everyday. 
It was the faces of the ordinary and extraordinary, found in the streets and the brothels of Italy, which inspired Caravaggio to create the works that he did. He took two ostensibly unrelated subjects, combined them, and created works of beauty that changed the very notions of religious representation in art. In Caravaggio's rendering of the Madonna, for example, he used a common prostitute named Lena for his composition. She was later to show up in a number of Caravaggio's paintings of religious themes. The painting of Madonna and child was taken down from its place in Saint Peter's because, according to Bellori, the virgin with the naked baby Jesus was indecently painted.

He was probably right, particularly if the Cardinals picked up on Lena's identity. As old Anne faded into the dank gloom of the background wall, and in the absence of anything else to catch the eye except the snake, Lena's prominent pale breasts, and a warmly sexual portrayal of the Christ child with his little jutting dick prominently shadowed on his inner thigh would've been all, when the painting was installed, you would've noticed. (Robb, 1999, p.333).

We would say that Caravaggio was creative, in that he reworked the idea of religious paintings by introducing an uncommon element into his subjects. The images and faces of common people, of prostitutes and beggars, filled his canvases with a representation of sixteenth century that was virtually unheard of in paintings of this time. Caravaggio broke the rules and created something beyond the canonical, something that was to both excite and anger the Catholic Church. By some he was condemned, while others lauded him for his creative achievements and the tenacity to take his work into a new realm. Caravaggio took the subjects and objects that surrounded him and reworked them into representations of religiosity, that offered a different use of subject and composition in sixteenth century painting. 
Now is Caravaggio's conception of painting an example of Schopenhauer's notion of aesthetics and creativity? This is a difficult question to answer, especially given that Caravaggio himself was a very complex man and exemplified a manner of artistic expression that at the time had no rival. In keeping with the notion of 'disinterestedness' and the unlimited nature of curiosity-driven creative expression, Caravaggio would not fit into the conception of a will-less creativity that is at the core of this notion of will-less creative activity. Having made this assertion somewhat arbitrarily, and without confirming my findings with a knowledgeable art historian, I will suggest that perhaps Caravaggio's form of creative expression is best understood as an aesthetic re-conception and subsequent representation of religious Icons and artifacts, a re-imagining and reconfiguration of religious art through the medium of painting and Iconoclastic denouncement. In this manner, and as an example of an 'interested' rather than 'disinterested' creative expression, we might suggest that Caravaggio painted with a will, or interest, that was marked by a re-representation of religious art, deriding and undermining sixteenth century religious art and artifact. Caravaggio's paintings are an example of a determined aesthetics, a willful and subject driven art form. He painted with a political and ideological subjectivism, one that allowed him to express his disenchantment with the current religious and political ideologies of his times. His paintings were well thought through, his choice of subject, models and counter-religious themes attest to that.

The artist is conscious of the world and of himself as a subject in that world. Patrick Gardiner writes,

Common to each [artist] is a certain emancipation from the trammels of everyday existence and from the modes of thought and awareness which are inseparably 
part of such existence. It is this that enables them to 'stand back', so to speak, from experience and from the complex scheme of relations which in the ordinary way determine its structure for us, thereby achieving a type of apprehension so remote from the customary one that attempts to communicate its content may in some instances initially meet with blank incomprehension or utter astonishment; an essential attribute of the great artist or philosopher consists indeed in the fact that 'he cannot go hand in hand with the existing regular culture of his age, but flings his works far out on the way in front...' (Gardiner, 1963, pp. 88-89).

The artist by his or her nature is imaginative and curious; he or she looks for the commonality in the uncommon, or the uncommon in the commonality of things; discovering and creating through imagination and curiosity, connections, or in some cases disjunctions where none were visible before. Presenting a view of the world, of things, objects and ideas in that world, that are new and novel; and in so doing, engaging and encouraging us to experience something for the first time, as if through 'disinterested' eyes. The imaginative and curious person expresses 'things' in a creative manner that looks beyond and behind pre-existing artistic concepts, with a 'disinterestedness' that is both inimitable and unyielding.

The artistic genius may in fact perceive things differently than the inartistic individual. He or she might be capable of drawing artistic impressions from the ideas of things that he or she apprehends freed from the constraints of the will. According to Schopenhauer, the most ordinary objects appear completely new and unfamiliar to the artistic genius. For the artistic genius there exists a composition of things that are not apprehensible through the willing intellect. Schopenhauer maintained that aesthetic awareness constitutes knowledge, and that this knowledge is capable of affording an insight into reality of a higher order than that available through scientific inquiry. What we are left with is a worldview conceivable outside of the trappings of the will itself and 
representational perception in general. These worldviews are apprehensible by the artistic genius through the function of imagination, intuition and creativity.

In conclusion, Schopenhauer contends that through disinterested aesthetic the will completely vanishes from consciousness. Aesthetic apprehension exists only when consciousness is subdued. In this realm of suspended consciousness the creative individual, or genius, is set free into a domain of apprehension that is independent of ordinary perception and representational apprehension.

This suspension of will poses difficulties for Schopenhauer's notion of aesthetic apprehension. If we grant that a direct suspension of willing is possible, then the notion of perception is done away with and we are left with a non-representational apprehension of the world as it is represented to our apprehension. We cannot have both a representational concept of reality, or phenomena, and one entirely lacking in such apprehension. The apprehension of things and their composition, however, may give us a clue as to what it is we experience in this creative will-less state. Impressions and memories drawn from the unconscious may, in fact, be fundamental to creative activity itself. The idea of a 'disinterested' apprehension and expression of creativity, aligned as it is with curiosity, imagination and an immitigable and un-impinging representational outer world, allows for a creative expressionism that is engendered and nurtured form within, from an 'innerness' where newness and novelty prevail.

Schopenhauer never conceived a notion of creativity; all he left us with was his work on aesthetics and his fundamental philosophical system. From this discourse, however, we can build a structure that might reveal what his notion of creativity may have been if he had chosen to write about it. Schopenhauer's contribution to the concept 
of creativity stands on its own as an example of a world-view that stressed the importance of the arts, literature and music in the understanding of what it is to be human.

Schopenhauer's contention was that this will-less state of apprehension that we arrive at in aesthetic contemplation is important to our understanding of philosophy in its entirety, including politics, ethics and metaphysics, as it allows for a free play of curiosity, imagination and creative apprehension.

\section{Chapter Two, Freud}

Now we will look at Freud's notion of creativity and its impact on psychoanalytical theory. Freud's conception of a creative force in the psyche begins with the idea that creativity is discoverable in most individuals, and that we can find a way into creativity by looking at the psychological structure of creative activity. From there we can define the qualities that are apparent in creativity and try to better understand the impact it has on the artist and the individual in general. Freud believed that creativity started in childhood and is also present in adult fantasies and the acts of displacement, sublimation, dreams, and the unconscious or primary process. Although Freud wrote very little on creativity with the exception of, 'Creative Writers and Day-dreaming', he did leave us with an interesting view of the creative process in relation to psychoanalytical theory.

In Freud's work, entitled 'Creative Writers and Day-dreaming' written in 1908, he introduces the reader to the notion of creativity and psychoanalytic process. Freud equated childhood play with creativity and imagination, seeing the child's idea of play as 
an attempt to redefine through creative means the world through the imagination. Freud writes,

Might we not say that every child at play behaves like a creative writer, in that he creates a world of his own, or, rather, re-arranges the things of his world in a new way which pleases him? (Freud, 1990, V.14, p.131-32)

In their games and activities children try to re-define the world by creating means of understanding reality that appreciate and enhance their specific understanding of the processes and phenomena of that world.

Creativity is the capacity to discover novel ideas from the phenomena present both in consciousness and the unconscious. For Freud a work of creativity begins its journey in the unconscious as an infantile wish or fantasy, and is then drawn through sublimation to create a work of art. (We will look at sublimation later on in the inquiry.)

Freudian psychoanalysis places imaginative acts in the primitive, or primal, and the 'infantile': creativity is found in the wish fulfillment of childish ideals and thereafter in the dispensation of fantasies in adult life. Freud's contention that creative acts may arise from childhood trauma is well known. He foresaw the potency of infantile fantasies in creative activity. Csikszentmihalyi writes,

According to Freud, the curiosity at the roots of the creative process--especially in the arts-is triggered by a childhood experience of sexual origin, a memory so devastating that it had to be repressed. The creative person is one who succeeds in displacing the quest for the forbidden knowledge into permissible curiosity. The artist's zeal in trying to find new forms of representation and the scientist's urge to strip away the veils of nature are really disguised attempts to understand the confusing impressions the child felt when witnessing his parents having sex, or the ambivalently erotic emotions toward one of the parents. (Csikszentmihalyi, 1996, p.100) 
Freud referred to the child as a processor of imaginative activity. When playing the child uses his or her imagination to 'recreate' notions of reality. Freud suggests that the creative writer in many ways exemplifies the child's need for imaginative play drawn through to adulthood.

The creative writer does the same thing as the child at play. He creates a world of phantasy which he takes very seriously--that is, which he invests with large amounts of emotion--while separating it sharply from reality. (Freud, 1990, V.14, p.132)

In adult terms, creativity allows the writer to recreate realities to satisfy an inherent need to create order out of the disorder of commonly experienced situations and environments. Creativity allows us to rearrange the terms of reality and enhance the notions of imagination and fantasy. In this manner fantasy plays an integral role in the notion of creativity. Fantasies represent wish fulfillments that are common to all individuals, though not always accessible. We fantasize in order to fulfil needs that cannot be satisfied in reality. As Freud explained,

We may lay it down that a happy person never phantasies, only an unsatisfied one. The motive forces of phantasies are unsatisfied wishes, and every single phantasy is the fulfilment of a wish, a correction of unsatisfied reality. (Ibid. p.134)

These fantasies include sexual or erotic leanings that are affected by the oedipal conflict and impact the imagination and creativity of the individual. In the Oedipal conflict the male child holds feelings of love and attachment to the mother, while holding anger and hostility towards the father. In the young girl the process is understood as the reverse, as she directs her attachment to the father. These activities fit themselves into the 
individual's 'shifting' impressions of life and change with every change in that individual's situation.

What it thus creates is a daydream or phantasy, which carries about it traces of its origin from the occasion which provoked it and from the memory. (Ibid. p.135)

Imaginative activity is a cornerstone of the creation of fantasies, as it enables the repressed to find expression in symptomatic behaviours, which are present in the acting out of the fantasy. Freud writes,

As people grow up, then, they cease to play, and they seem to give up the yield of pleasure which they gained from playing. But whoever understands the human mind knows that hardly anything is harder for a man than to give up a pleasure which he has once experienced. Actually, we can never give anything up; we only exchange one thing for another. What appears to be a renunciation is really the formation of a substitute or surrogate. In the same way, the growing child, when he stops playing, gives up nothing but the link with real objects; instead of playing, he now phantasies. He builds castles in the air and creates what are called day-dreams. (Ibid. p.133)

In Gay's book, Freud on Sublimation, sublimation is a means through which the artistic individual finds some satisfaction in rendering his/her sensual and erotic sentiments through the work of art. This allows the artistic individual the capacity to give life, through art, to his/her deepest thoughts and beliefs. Rycroft's definition of sublimation is as follows:

Sublimation. Developmental process (see development) by which instinctual energies (see instinct) are discharged (see discharge) in non-instinctual forms of behaviour. The process involves (a) displacement of energy from activities and objects of primary (biological) interest on to those of lesser instinctual interest; (b) transformation of the quality of the emotion accompanying the activity such that it becomes 'desexualized' and 'deaggressified' (desexualization and deaggressification); and (c) liberation of the activity from the dictates of instinctual tension. (Rycroft, 1995, p.176)

Sublimation changes sexual instincts into creative ones; it realigns the wish fulfillment of night-dreams and daydreams and engenders a specific activity of 
imagination and creativity in the artist or scientific individual. From sublimations are drawn artistic and imaginative notions that derive their energy from sublimation of sexual instincts to creative endeavors. La Caze writes,

The fundamental idea behind sublimation is a familiar one: when sexuality is sublimated, it is transformed into something higher and finer, more 'sublime' such as art or intellect and scientific achievement, or work in general. Freud says that sexual instinct, as opposed to other instincts such as hunger, is particularly able to contribute to professional activity of various kinds because of its capacity for sublimation. (La Caze, 2000, p.261)

The fantasies that are generated in childhood affect the way an adult perceives the world. These infantile wishes when carried into adulthood may give rise to fantasies that still have vestiges of childish desires and attitudes. In many ways the creative writer looks for ways to enhance his/her experiences through the attainment of pleasure drawn from a work of fiction. What the creative writer does is to construct a literary world where he/she has complete control over reality, or a world of their creation. A work of literature may, in some instances, represent a release of psychic energy or a projection of dissatisfaction in present experience.

A work such as Proust's, Remembrance of Things Past, is a fine example of the writer working out his or her dissatisfaction in an autobiographical novel. Proust kept it no secret that the protagonist in his novel was a characterization of himself. In this manner the creative writer often overcompensates for the persistent failures he experiences in his reality-based world, and builds a possible phantasy-equivalent. Infante writes,

He [Freud] then shows us that children in play create a world of their own, rearranging things in a new way that pleases them, and that this is essentially the same as what poets, novelists and dramatists do. (Infante, 1995, p.53) 
According to Freud, the real pleasure afforded by a creative work comes from the discharge of tensions. From this we may conclude that the act of creativity is one in which discomfort and displeasure are suspended and an idealized fantasy-equivalent is introduced in its place. The true genius of creativity exists in the ability of the creative artist to suspend these images of displeasure and extend the fantasy-world into a work of art, which exemplifies a reality that affords pleasure and satisfaction. Through the rearrangement of infantile and adult fantasies the creative individual builds a reality he/she feels comfortable inhabiting. Even though this reality exists as an answer to psychic tension, it also exhibits the artist's ability to reformulate the phenomena and create a fantasy-reality that overcompensates for a loss of childhood notions of play.

Creativity carries with it a coalition of daydreams, night dreams and fantasies that all have one thing in common: they enable the individual — and not just the artist- to engage him/herself in the activity of imagination and recreation. By recreation I mean the reassemblage of ideas and fantasies that impact on the individual's capacity to alter the meaning of their specific realities. Creative works of art, for example, show us what the artist him/herself sees in this reassemblage of fantasies and notions of reality; they allow us to get an insider's look at how the artist experiences the phenomena of reality and fantasy.

The Ego plays an important part in the overall structure of the psyche. The Ego is situated topographically between the Id, or pleasure principle, and the Super-Ego, the seat of social and moral coding. The Ego, as such, mediates between the outer and inner, the desire to maximize pleasure through the Id, and the coded mores and laws of society as understood first in parental rules and expectations, then later in societal and interpersonal 
relationships. In contrast, the Id represents the ongoing sexual tension and need for satisfaction that is common to the psyche and is at constant battle with the Super Ego, which represents the censor and social mores of the environment and society in general. Freud was interested in the notion that writers, in general, have the capacity to 'split' their egos into redefined portions.

The psychological novel in general no doubt owes its special nature to the inclination of the modern writer to split his ego, by self-observation, into many part-egos, and, in consequence, to personify the conflicting currents of his own mental life in several heroes. (Freud, 1990, V.14, p.138)

The Libido is in constant tension with the Super Ego and expresses itself in fantasies and in wish fulfillment that the Super Ego tries to censor and destroy. Egosplitting influences creativity and it helps identify the defining points of each character. On Freud's account, in a novel like Ulysses, characterization is achieved through the differentiation of Joyce's character into characters in the novel; they represent a split-ego. Of course this may only be conjecture, and Joyce's ego may not be represented, or split, in his characters, but for the purposes of this inquiry we might accept it as plausible.

Ego splitting generating the fictional characters in a work of literature allows the creative writer to assume the character of the hero or villain, reestablishing the primary role of childhood play and fantasy. This can be done either on a conscious level, as in Proust, for example, or unconsciously, without the writer being aware of the process. In this manner Freud saw fantasy as a function of the ego. The 'primary process' is governed by the pleasure principle (as we will see later) and seeks out gratification without recognizing reality. Infante suggests that,

We may begin by asserting that every artist has an urge to reaffirm his existence by expressing feelings and emotions that cannot be conveyed through the usual channels of communication. (Infante, 1995, p.61) 
The gratification of these wishes represents the function of the ego to find satisfaction in the world of fantasy. Fantasy can be understood as a mediator between consciousness (secondary process) and unconscious (primary process). The primary process is the birthplace of the ego; and the ego itself is the starting point of all fantasy. If we allow for this, then the unconscious is the architect of all further psychic functioning and fantasies are derivative of the need to satisfy wishes generated in both childhood and adult reality.

The notion of 'repression' plays a fundamental role in creative activities. Repression is the process by which an unacceptable impulse or idea is rendered unconscious. (Rycroft, 1995, p.157) The unconscious is fertile ground for creative activity. In the unconscious the repressed ideas are sublimated into artistic or scientific activities, and form the basis for much creative work. Anxiety is linked to these repressed fantasies or ideas. We may postulate that some creative energy is exposed to anxiety in repression, and therefore manifests itself in works of art that are, by their very nature, the result of this repression. When unpleasant tensions increase and become anxiety-ridden, the wish-fulfillment function of the primary process drives these tensions into the unconscious where they pick up the vestiges of infantile wishes and desires. We might conjecture that infantile wishes are one focal point for creative activity, and that they are the end result of repressed ideas. These instinctual demands on the unconscious are drawn into the drama of creative ideation and form the basis of much creative activity. From this world of unconscious psychosexual desires, and the drive for 'wishfulfillment', creative activity is produced through the act of sublimation.

The 'primary process' was considered by Freud to be primitive and concerned with unconscious thinking. The function of the primary process, or Id, is to reduce the 
unpleasure of instinctual tension by hallucinatory wish fulfillment. These instinctual wishes often end up being sublimated into creative energy, reducing the sexual tension and allowing the individual to express him/herself in artistic or scientific terms. The primary process is a sort of storehouse for the possibilities of creative energy. The 'secondary process' is governed by the 'reality principle' and reduces the unpleasure of instinctual tension by adaptive behaviour. (Rycroft, 1995, p.138) The 'secondary process' is conscious and related to the ego and adaptation to the external world. Freud believed that the 'primary process' was an earlier manifestation than the 'secondary process'. The primary processes are exemplified in dreaming and the secondary process in thought. Daydreaming, imagination and creative activity reduce instinctual tensions necessary for creative endeavors. According to Freud,

The nucleus of the [Ucs.] consists of the instinctual representation which seek to discharge their cathexis; that is to say, it consists of wishful impulses. These instinctual impulses are co-ordinate with one another, exist side by side without being influenced by one another, and are exempt from mutual contradiction. (Freud, 1990, V.11 p.190)

The unconscious is not governed by the process of time; images and representations may have been stored many years before a creative work is realized. In this manner creativity is not held under the constraint of time; it is timeless. This timelessness adds to our notion of creativity being non-temporal or spatial phenomena. As Freud wrote of the unconscious in On Metapsychology,

The process of the system [Ucs.] are timeless; i.e. they are not ordered temporally, are not altered by the passage of time; they have no reference to time at all. Reference to time is bound up, once again, with the work of the system [Cs.]. (Ibid. p.191) 
Creative activity can be drawn from the past, in the unconscious, and from the present, as in the previous day's residual images. These residual images, which are found in dreams, are examples of the present-ness of psychic activity; they belong to the past day's activities, and in many ways represent the dream activity of all individuals.

Past and present memories and experiences also have an impact on the creative process of the writer.

A strong experience in the present awakens in the creative writer a memory of an earlier experience (usually belonging to his childhood) from which there now proceeds a wish which finds its fulfillment in the creative work. The work itself exhibits elements of the recent provoking occasions as well as of the old memory. (Freud, 1990, V.14. p.139)

And,

The core of his nature, and the secret of it, would appear to be that after his curiosity had been activated in infancy in the service of sexual interests he succeeded in sublimating the greater part of his libido into an urge for research. (Ibid. pp.170-71)

As introduced earlier, Freud believed that the libido plays a key role in the creation, not only of works of art, but scientific research also. Freud's notion of fantasy has made an important contribution to creativity. Elliott writes,

Once Freud granted fantasy an active and subjective dimension, therefore, the psychic realm no longer functioned as a mirror to objective reality. Freud had uncovered, in one stroke, the creative radical imagination. (Elliot, 1999, p.6)

This insight occurred when Freud gave up his notion of the seduction theory in 1897 and recognized that fantasies might be understood in a different way. It was with the suppression of the seduction theory that Freud changed his view on hysteria and sexual abuse. He believed that incidents of sexual abuse were actually fantasies that the individual had about the father, not actual occurrences at all, but they could very well be 
imaginative or creative. Freud conceived of these fantasies as signs of the unconscious intentions, not necessarily repressed memories of childhood trauma. If this were so, then the imagination and fantasy play crucial roles in unconscious formulations. Toews writes,

From this perspective 'embellishments' and 'sublimations' of fantasy were not so much outworks to be demolished as obscure revelations of a different kind of truth, the truth of unconscious psychical activity. They were openings into a hidden world of 'psychic reality' that was not passive and objective but active and subjective, a world of unconscious psychosexual desire. (Ibid. p.6)

From this world of unconscious 'psychosexual desires', creative activity is produced through the act of sublimation. To accept the fundamental and radical creativity of the imagination, one need in turn accept the notion of sexual impulses being governed by the unconscious, and therefore subject to the vicissitudes of sublimation. A preoccupation with unconscious sources of human thought has served to reinforce the notion of creativity as an unconscious sublimation of sexual instincts. The unconscious, it might be conjectured, is a warehouse for creativity, present, past and future. Creativity, as suggested earlier, is influenced by repression; through the processes of sublimation, condensation and displacement, the individual reworks sexual wishes and desires that are experienced in childhood into acts of creativity. Freud writes,

A strong experience in the present reawakens in the creative writer a memory of an earlier experience (usually belonging to his childhood) from which there now proceeds a wish which finds its fulfillment in the creative work. The work itself exhibits elements of the recent provoking occasion as well as of the memory. (Freud, 1990, V.14, p.139)

Freud recognized that the process of creative writing involved the use of 'primitive' forms of thinking. It is this 'regression in the service of the ego', which represents the primitive formation of creative thought. It is here that we see the 
conditions and processes of condensation and displacement in the primary process. Condensation operates in such a manner that part-images represent wholes and, in this way, yield novel combinations. From this we might suggest that the creative individual accesses childhood images or re-imaginations, but also goes well beyond infantile repressions and sublimations.

Fantasies generated in childhood affect the way an adult perceives the world. From these infantile wishes come the process by which the mental functioning of the adult gives rise to phantasies in the present that may, or may not, be colluded with childhood fantasies. By this I mean that the creative writer, for example, looks for ways to enhance his/her experiences through the attainment of pleasure drawn from a work of fiction. What the creative writer does is to construct a literary world where he/she has complete control over the reality, or world, they are creating.

Unconscious elements, as I have suggested, find their way by means of the creative process into the present representation that we refer to as a work of art. A creative writer or poet might find that they have no idea how a past image found its way into their work of art. The process by which this imagining occurs is, by its very nature, an activity that is affected by the unconscious. Lemlij suggests that,

A conscious thought offers itself to the secret alchemy of the unconscious, which re-creates it with a distinct, paradoxical mysterious lucidity, and returns, in its novel complexity, to the consciousness that rediscovers it, reformulating it in works of art or manifest dreams. (Lemlij 1995, p.169)

We will now take a look at dreams and their relationship to the unconscious and creativity. Dreams form an interesting template by which to understand the creative process; they are hidden storehouses of creative activity and material. Dreams contain material that actualizes the unconscious mental process and imagine realities that are 
functional only in the dream state. The creative activity found in dreams is processed and used by many artists as a material for their work. The manifest content of the dream is that which is remembered upon waking; the latent content is interpreted from the manifest content; we first remember the manifest dream and then go on to discovery its latent content. Freud writes,

We are tempted to study the process by which the latent dream-thought were transformed into the manifest dream. We call this 'dream work'. (Freud, 1990, V.2, p.46)

According to Freud, the 'dream work' gives us the first glimpse of the processes that takes place in the unconscious. Through these residual images can be discovered what has been going on in the mind of the dreamer leading up to the dream itself. The dream, in this fashion, might be a part-answer to the dreamer's state of mind, or an answer to a problem or question. Unconscious images contribute to the creation of a dream.

In every dream an instinctual wish has to be represented as fulfilled. The shutting-off of mental life from reality at night and the regression to primitive mechanisms which this makes possible enable this wished-for instinctual satisfaction to be experienced in a hallucinatory manner as occurring in the present. As a result of this same regression, ideas are transformed in the dream into visual pictures: the latent dream-thoughts, that is to say, are dramatized and illustrated. (Ibid. p.47)

This regression to instinctual wishes in the unconscious allows us to further understand the notion of dreams as a function of creativity. The creativity to be found in dreams, primarily latent dream-thought, is a process by which the images and unconscious wishes that the dreamer experiences are given a creative representation. This creative representation can be comprehended as an instinctual reaction to an unpleasant thought, or a striving towards a satisfaction of a particular instinctual wish. 
The latent dream thought, before it is subjected to interpretation and manifestation, is where a lot of creative activity is to be found. The instinctual wishes and residual images that impact on the dreamer while in the dream state generate this creative energy. Freud writes that,

The motive forces of phantasies are unsatisfied wishes, and every single phantasy is the fulfillment of a wish, a correction of unsatisfying reality. These motivating wishes vary according to the sex, character and circumstances of the person who is having the phantasy; but they fall naturally into two main groups. They are either ambitious wishes, which serve to elevate the subject's personality; or they are erotic ones. (Freud, 1990, V.14, p.146-47)

These fantasies and wishes are the material from whence creativity is generated.

The satisfaction of these wishes and fantasies in the dream-state culminate with a representation of a desire that answers to the dreamer's needs and satisfactions. Not all dreams, however, are satisfactions of instinctual wishes. There are those dreams that cause the dreamer to repel in fear and find little solace in the message of the dream itself. There are also those dreams that relate to the erotic wishes of the dreamer and may find extension in the expression of sexual desire and longing. These dreams are the representation of a fantasy that the dreamer has as a wish-fulfilment that needs to be satisfied. The creative element in these dreams has to do with the manner in which these dreams, or instinctual-wishes, are expressed in the latent dream.

Unconscious impulses are the true creator of dreams; they produce the psychical energy for the dream's construction. Freud writes,

Like any other instinctual impulse, it cannot strive for anything other than its own satisfaction; and our experience in interpreting dreams shows us too that that is the sense of all dreaming. In every dream an instinctual wish has to be represented and fulfilled. (Freud, 1990, V.2, p.47) 
Ideas are transformed in the dream into visual pictures; these are the latent dreamthoughts that represent the ongoing tension present in unconscious activity. This tension necessitates a discharge of psychic energy that will enable the dreamer to satisfy a need or erotic desire. This satisfaction can take the form of a creative intervention that the dreamer utilizes to represent that dream-thought itself. This creative intervention, or activity, is dependent on the dreamer's ability to access things that may be repressed yet present in the unconscious.

Through the unconscious latency of the dream-wish, the dreamer arrives at a creative answer in the dream activity; or the dreamer uses creativity to represent the dream-image in the dream itself. In either case, the activity generated by the dream is represented in the creative activity that follows the latent output of the dream. What is interpreted might be less creative than what is manifest, and in this manner, the interpretation serves to change the dream image into something understandable to the dreamer, and in doing so, tampers with the fresh image that the dream in it its primary state affords to the dreamer. Freud writes,

Let us go back to the latent dream-thought. Their most powerful element is the repressed instinctual impulse which has created in them an expression for itself on the basis of the presence of chance stimuli and by transference on to the day's residues-though an expression that is toned down and disguised. Like every instinctual impulse, it too presses for satisfaction by action; but its path to motility is blocked by the physiological regulations implied in the state of sleep; it is compelled to take the backwards course in the direction of perception and to be content with a hallucinated satisfaction. The latent dream-thoughts are thus transformed into a collection of sensory images and visual scenes. (Ibid. p.48)

These fantasies are influenced by creativity and are represented in pictorial form in dreams themselves. We have a picture of the dream in the dream-state that is infused 
with creative qualities that are representative of the unconscious psychic activity of dream-thought itself.

The comparison of the dream content with the dream thought is evident before an interpretation is attempted. Through the processes of displacement and condensation, the dream takes on a different thought structure, one that may not be present in the manifest state. In displacement, energy is transferred from one mental image to another; and in doing so, the latter becomes an equivalent or substitute for the other. In condensation, two or more images are combined to create a composite image, which is then invested with meaning and energy derived from both. We might consider the combination of these two or more images, and the transference of one image to another, as examples of a creative mental thought process. The dream compresses, distorts, displaces, and disguises the dream-thoughts in such a manner that the manifest content bears little resemblance to the latent content. These mental functions serve to further enshroud the latent content of the dream, until an interpretation makes sense of a dream considered for interpretation. I suggest that not only through the art of interpretation, but also during the processes of displacement and condensation, low levels of creativity may be found as an active mental phenomenon in dreams and dream work. Infante writes,

In my view, the function of artistic creation is similar in many ways to that of dreaming. Like the later, it often represents the fulfillment of repressed wishes or an attempt to work through traumatic or mourning situations; it sometime serves to convey messages. A fundamental difference between them is that, whereas the mode of thought in dreaming is predominately that of the primary process, in the case of art there must be an appropriate relationship between the primary and secondary processes. (Infante, 1995, p.61)

The unconscious process is central to our understanding of creativity; it helps us to better comprehend the complexities of artistic expression. The use of dreams and 
dream interpretation is also of importance when looking at the process of the unconscious and creativity. Creativity, as seen through a Freudian perspective, is a multifaceted system that includes not only the primary process and the dreamscape, but also the way in which we understand our place in the workings of things in general.

Freud wrote little of import on creativity other then 'Creative Writers and Daydreaming'; however, we can extrapolate from what he did say about the unconscious, the secondary and primary process and sublimation and arrive at some interesting conclusions. Though we may not be able to pin down Freud to any one theory of creativity, we can, with some 'creativity' ourselves, postulate what he may have said if he had written more on the subject. We might say that creativity is not only a process of conscious thought, but also something dredged from the recesses of the unconscious where hidden and repressed wishes and ideas lay dormant. It is when these ideas and repressed wishes find fruition in conscious activities, that creativity finds a purchase in our thought processes. Creativity, as such, is a process itself, but one limited only by experience and one's ability to find new ideas and couplings between those ideas and representations.

Freud's notion of creativity might, at first glance, seem incomplete and unsatisfying; however, if we understanding creativity in terms of wish-fulfilments, unconscious desires, dream work, both latent and manifest, ego-splitting and repression, we come to see that creativity from a psychoanalytical perspective is full of interesting possibilities, and in many ways helps us to better understand the process of creativity itself. 
Chapter Three, Schopenhauer and Joyce

What does Schopenhauer's concept of disinterestedness have to offer to a reading of James Joyce's Ulysses? We might begin by looking at the structure of Joyce's narrative with regard to Schopenhauer's notion of the suspension of will and Joyce's use of inner monologue. Ulysses is a novel that allows the reader access to the interior thoughts of its principal characters. The Dublin of Joyce's Ulysses is inhabited by a host of characters whose lives are stayed with a pathological dreariness, a sense of their own isolation from Dublin society. Leopold Bloom's cuckoldry at the hands of Blazes Boylan and feelings of disconnection from Dublin society, and Stephen Dedalus' shame and guilt over his refusal to kneel in prayer with his dying mother depict the pathetic aloneness of the two principal characters in the novel. Ulysses portrays one day in the life of a cast of Dubliners and their and thoughts on life, love, sex, cuckoldry, politics, religion, philosophy and so on. The two principal characters, Bloom and Dedalus, ruminate on their failures and hopes, and their detachment from and indifference to themselves and the world. This disinterestedness is central to Joyce's use of monological narrative in Ulysses. In this chapter I explore the notion of disinterestedness in both Schopenhauer and Joyce, Schopenhauer's conception of the will and the notion of a disinterested narrator might help us to better understand Joyce's use of inner-monologue and streamof-consciousness as they pertain to the creativity found in Ulysses. It is important to note that Schopenhauer's conception of the aesthetic, which includes creativity, is best understood as a culmination of his philosophy of the 'will' and its application to the metaphysics of thought itself. He searches for a better notion of what it is to be creative, 
and finds it in that application of the will-less activity of aesthetic apprehension towards painting, poetry, literature and music. On the notion of an inner nature, Schopenhauer writes,

...he who seeks to know mankind according to its inner nature which is identical in all its phenomena and developments, and thus according to its Ideas, will find that the works of the great, immortal poets present him with a much truer and clearer picture than the historians can ever give. (Schopenhauer, 1969, p.246)

This 'inner nature' can be seen in Joyce's narrative and Schopenhauer's aesthetics, in that both work from an inner source of aesthetic apprehension. Schopenhauer's notion of a suspension of 'will' may allow us a better understanding of the creative process of Joyce's Ulysses.

The notion of will-lessness might allow us an unconventional understanding of how Joyce manipulated language, allowing us a look inside a work that exhibits a process of creativity, that while engaged in the world, also pulls away from it in an attempt to reach a disinterested aesthetic detachment.

Joyce carefully and painstakingly plotted the narrative in Ulysses as a way into the inner thought processes of the principal characters. Even though the Joycean character struggles relentlessly through the everydayness of life, he or she seems intransigently bound to the inner musings and confabulations of a monological reality. In this inner monologue Stephen, while teaching a class, reflects on the his pupil Sargent, who has written the word Sums on the headline of his copybook:

Ugly and futile: lean neck and tangled hair and a stain of ink, a snail's bed. Yet someone had loved him, borne him in her arms and in her heart. But for her the race of the world would have trampled him under foot, a squashed boneless snail. (Joyce, 1992, p.33) 
It is this detachment from the moment, the goings on in the classroom, and Stephen's switch to an inner monologue on the pupil Sargent, that best exemplifies the detachment from the outside that is common in Ulysses. Joyce's characters live in a one-dimensional world drawn solely from their own ongoing machinations and psychological experiences; and from within this narrative, each character narrates the inner process of his/her thoughts. Bloom, Stephen and Molly, for example, have inner narratives embedded in the ongoing theatrics in the outside world, which represent their inner thoughts as events particular to their psychological mirrors. In saying this, we may understand Bloom, Stephen and Molly's inner monologues as reactions to external social and interpersonal relations. This disinterestedness, or pulling away from the outside world, reveals an inner process of disinterested disinterestedness.

In Schopenhauer's system, as in Joyce's, there can be found a disinterestedness that engenders creative intuition and aesthetic apprehension. In Schopenhauer this is found in the apprehension and appreciation of a work of art, the pulling away, or disinterested apprehension of the work of art. In Joyce it can be found in the disinterestedness of his characters, the pulling away from the outside and concentration on inner thought. The difference between willful thought and a will-less intuition can be found in the way in which Schopenhauer conceives of aesthetics as belonging outside the constraints of the will. He pushes will-less thought into the aesthetic nature of creativity, and in doing so, takes us further away from the notion of a driven or desirous activity. It is important to note that Schopenhauer felt that aesthetic apprehension was attainable on a plane where desires are put in abeyance and will-lessness prevails. In this manner, 
Schopenhauer's conception of the aesthetic, from which we have extrapolated his notion of creativity, can be applied to Joyce's Ulysses in keeping with the philosophical notion of an inner process that is not actively engaged in the outer world, but recreating it after the fact. This inner process, as posited above, can be understood in the narratives of the main characters in Ulysses.

The notion of 'disinterestedness' suggests that aesthetic apprehension, and for our purpose creativity, is the product of a disengagement from the plane of desire-driven activity. In this manner, as we find in Joyce, the characters in Ulysses are not driven from something outside themselves, but from within their own private inner musings after the fact. What I am suggesting is a disinterested interest. Joyce's characters are disinterested in their own interests; they stand twice removed from the object of apprehension. In this manner they are disinterested in their own interest, twice removed from their own disinterestedness. This allows Bloom and Stephen to apprehend the disinterestedness of their own disinterest. In doing so, they have in effect pulled away from the first order of their disinterestedness, allowing for a disinterest of what was disinterested. In this manner Stephen's inner monologue on the pupil Sargent is twice removed from the first case disinterest, it exemplifies a disinterestedness in his own interest. By doing so, Stephen is able to recognize his disinterested disinterest. This twice-removed disinterestedness creates a solipsistic aloneness in the characters, an antipathy towards not only disinterestedness but also their own interest. In this manner Joyce's characters inhabit an inner narrative that is disinterested in itself. Of course this disinterested disinterestedness has consequences for Schopenhauer's theory of disinterestedness, pushing back the notion of disinterested aesthetic to a higher order 
disinterestedness' that precede the first order disinterestedness. In Joyce we might very well find a disinterested 'disinterestedness' that oversteps Schopenhauer's concept of disinterestedness. Which invites the question, how far back, or forward, can disinterestedness go?

The notion of disinterestedness runs parallel to our concept of will-lessness in that in both cases aesthetic and creative activity focuses in on the inner process of thought, blocking out external activity. In this manner the inner process as exemplified in Joyce's Ulysses, is freed from contingent, ongoing outer activities; to be in a position of 'disinterestedness' is to be suspended from the immediacy of perception. By perceptual thinking I refer to objects of thought that are in some way immediately attached to those 'things' they refer to. What is an event or, more precisely, a creative or aesthetic idea, is not something dependent on a perceptual correspondence. In Ulysses, for example, the character's monological associations are formed either after the fact, or in anticipation of some event or possible occurrence. In this manner, in Bloom's musing over Blazes Boylan's imminent sexual assignation with Molly, he is not relating his thoughts to something present, or at hand, but to a future event that he feels helpless to intercede in. His thoughts are not representative of something present, but to the idea extended into the future. This is also the case with respect to the inner monologues that each character creates after the fact; Bloom's thoughts concerning the Dignam's funeral, or Stephen's anxieties and guilt over his mother's death, for example. There is no immediate relation between the impending event and the thought itself; they are independent of each other, as are the events in the past. 
It is from this disinterested position, where each character is not actively engaged in the present, but projecting thought into a possible future event or remembering and reorganizing a past occurrence, where the process of an inner dialectic occurs. This pulling away from the immediate or present and the construction of inner thoughts is what characterizes Joyce's monological or narrative technique. Whether or not Boylan meets with Molly is of little importance here; it is the thought extended that is at issue, not the event itself.

As suggested above, creativity as understood in Schopenhauerian terms is concerned more with will-lessness than with willful aesthetic apprehension. Perhaps in this manner Bloom is the 'disinterested' creation of his own inner thoughts. His disinterested disinterest creates a monological narrative that he constructs and reconstructs, creating a solipsistic inner narrative of the world, his place in the world. This state of will-lessness, found in a 'disinterested' narrator such as Bloom, allows a writer such as Joyce the freedom to suspend himself from the apparent or perceptual, extending creativity onto a plane not unlike Schopenhauer's in that it is disinterested, but also disinterested in disinterestedness.

In this disinterested aesthetic the artist finds himself in a position of 'disinterestedness' which allows for the apprehension of an aesthetic detached from convention. In Joyce's Ulysses, the main characters Bloom, Stephen and Molly offer the reader a narrative portal through which to view the characters' innermost thoughts and feelings. This Joycean narrative and monological technique creates an imaginary mindscape personified by each character's 'disinterested' rendering of experience and dissatisfaction. In a disinterested disinterest, the characters find themselves trapped in an 
inner narrative, or monologue, that is aware only of it's own disinterest of the disinterestedness of disinterest. In this way nothing other than their disinterest can interfere with the apprehension of disinterest. Yet their disinterestedness seems to quash any attempt at a first-order disinterest, encouraging a solipsistic inner narrative. In this way, perhaps, Ulysses can be experienced as a work of 'disinterested' aesthetic, one in which each character's narrative voice exists independent of an objectifiable world.

Albert Einstein, in an address given at the celebration of Max Planck's birthday, delivered the following speech,

To begin with, I believe with Schopenhauer that one of the strongest motives that lead man to art and science is escape from everyday life with its painful crudity and hopeless dreariness, from the fetters of one's own shifting desires. A finely tempered nature longs to escape from personal life into the world of objective perception and thought; this desire may be compared with the townsman's irresistible longing to escape from the noisy, cramped surroundings into the silence of high mountains, where the eye ranges freely through the still, pure air and fondly traces out the restful contours apparently built for eternity. (Einstein, 1954, pp.224-5)

This quote from Einstein suggests that the artist and scientist search for objectivity outside the 'drives' and 'desires' of everyday life, which, as we have seen, is the fundamental precept of Schopenhauerian creative activity. Joyce's search for a way around conventional literary style lead him further away from the prevalent notions of narrative and structural technique, into a yet to be charted aesthetic terrain where he could let his creative imagination run free and unobstructed.

The process involved in reading a book like Ulysses creates its own set of problems. With the misspellings and the use of puns introduced throughout the work, the reader finds him or herself drawn into an autonomous world derived from the innernarration of its characters. In this narrative world of monological inner-thought, perhaps 
Ulysses can be best read from a disinterested position. We bring to the novel our own ideas and conceptions that help to flavor our experience of the book; and in doing so create our own inner-world of Joycean characters. In this manner the unconscious narrative voices allow the reader access to the inner thoughts of each character; and perhaps if we allow ourselves the indulgence, to a better understanding of our own unconscious processes. (We will take a further look at unconscious play in Ulysses in the chapter on Freud).

In reading Ulysses we are drawn into a narrative that is interwoven with the inner thoughts of its main characters. Through Bloom, Stephen and Molly, Joyce allows us entry into the inner-workings of his characters; and through them we are given a better understanding of their inner lives. We find ourselves almost suspended in a state of 'disinterest' that allows us, the reader, to get inside the thoughts of each character in Ulysses. In this manner Joyce's conception of Ulysses can be understood as a disinterested narrative that is will-less in character in a Schopenhauerian sense of the term will-lessness. By will-less, again, is understood the process of being inside an aesthetic or creative apprehension that has no representation to anything outside of itself. In this manner, we are drawn into the inner thoughts of Joyce's characters and away from the 'interestedness' of things outside of this will-less or disinterested apprehension. Perhaps Joyce's attention to detail and his extensive editing and rewriting of Ulysses can be seen as Joyce suspending himself from the world that surrounded him. In doing so he was free to experiment with the notion of an aesthetic work of literature that was derived from a 'disinterested' attachment to the work itself. This 'disinterestedness' allows the reader to get 'inside' each character's thoughts and for that time experience a freedom 
from the interestedness of his/her own world. It represents a reality where the reader is not 'driven' or 'desirous' of anything outside of the novel, creating a purely objective or aesthetic apprehension of what is read. According to Schopenhauer, this will-less state allows us entry into the aesthetic realm of the artist as writer.

As previously suggested, Ulysses represents an inner or unconscious process that is drawn from the narratives of its primary characters. Joyce created a fictional world that was representative of the unconscious process and the notion of a will-less or disinterested apprehension of each character. From within this unconscious aesthetic, apprehension is possible from an 'inside' or 'disinterested' perspective; or as the case may be a disinterested interest.

In Ulysses Joyce conceived of a fictional world where the inner thoughts of its characters were given full reign, and inner monologue is used to narrate a difficult and often exasperating story. In Ulysses, we are challenged by Joyce to 'decode' the material in the narrative and come to an understanding of the way in which the material is presented to the reader. In the narrative-the inner monologue-Joyce uses this 'disinterested' voice in a manner that isolates each character in a psychological innerworld; he magnifies the thought process and in doing so creates a fictional world that thrives on stream-of-consciousness narrative. (The commonalties between free association and stream-of consciousness in Ulysses will be explored in the chapter on Freud and Joyce).

Ulysses is a book of free-floating association; it is characterized by a narrative style that suggests a 'disinterested' and solipsistic world in which each character is cloistered and detached from meaningful relationships with others, dispensing with all 
possibility of change and fulfillment. As in the failed relationship between Molly and Bloom and their inability to find a source of comfort and reconnection with each other after the death of their son Rudy, Joyce's characters inhabit a lonely and disaffected world that was presaged by Schopenhauer's philosophical pessimism. Joyce's characterization of detachment and disconnection in Ulysses suggests that the Dublin he left with such haste and disfavor years earlier found its way into his fiction through the inner narratives of his main characters.

Joyce's Ulysses can be read as a comedic tragedy in which its main characters experience the monotonous pains of ordinary living, and through these tragedies try to discover some form of redemption in light of their suffering. This striving towards disinterestedness is a constant theme in Schopenhauer. The main protagonist in Ulysses, Bloom, in his travels through Dublin finds himself caught up in an endless stream-ofconsciousness thought that revolves around the failures of his past and the dissatisfaction of the present.

What then does this suffering and tragedy have to do with creativity? In Joyce the constant striving for satisfaction is a theme that repeats itself through Ulysses. Bloom is constantly at odds with feelings for Molly and his need for sexual and existential fulfillment. The need for a way out of this dissatisfaction impels each character to search for a way out of unhappiness and tragedy. In Joyce this satisfaction eludes its primary characters, they continue to exist in a world of unhappiness and tragedy. The grief and guilt that haunt Stephen after the death of his mother:

In a dream, silently, she had come to him, her wasted body within its loose graveclothes giving off an adour of wax and rosewood, her breath bent over him with mute secret words, and a faint odour of wetted ashes. Her gazing eyes, staring out of death, to shake and bend my soul. On me alone. The ghostcandle 
to light her agony. Ghostly on the tortured face. Her hoarse loud breath rattling in horror, while all prayed on their knees. Her eyes on me to strike me down. Liliata rutilantium te confessorum turma circumdet: iubilantium te virginum chorus excipiat. Ghoul! Chewer of corpses! No mother. Let me be and lest me live. (Joyce, 1992, pp.10-11)

Stephen is less concerned with his mother's death, than with his inability to free himself from the guilt and shame he feels for not being a good son. Joyce's characters inhabit an 'inner world' of cold 'disinterest' where their thoughts are alone and uncommunicative to anyone except themselves. In the end Joyce's characters remain trapped, captive to their own inner pessimism. This encourages disinterestedness from disinterest, twice removed from the disinterested. In this way Stephen is looking at himself looking at himself, twice-removed from the object of disinterest. Even a cold dispassionate disinterest would be too much to bear.

Schopenhauer understood man as a creature for who hope and happiness are but fleeting occurrences. The wish for something happy and fulfilling was a difficult undertaking at best. Schopenhauer writes,

The reason the sudden announcement of a great piece of good fortune can easily prove fatal is that happiness and unhappiness is no more than the ratio between what we demand and what we receive, so that we are not sensible of the goods we possess or are quite certain of possessing such; because all enjoyment is really only negative, only has the effect of removing a pain, while pain or evil, on the other hand, is the actual positive element and is felt directly. (Schopenhauer, 1976, p. 168)

Schopenhauer's concept of sexual drive gives us insight into Joyce's Ulysses, allowing us a picture of the sexual dissatisfaction of the principal characters. In each we find a dysfunctional relation between sexual longing and wholeness, drawing us into a world of failure. Sexuality was important for Schopenhauer: he developed a metaphysics of the body based on the focal point of will in sexuality. Safranski writes, 
As a rule, he taught, we do not stand a chance against our sexuality. As the most garish manifestation of 'will' it is the 'thing in itself' in action, humiliating the poor ego and sweeping it along before it. In his unsatisfactory relationships with woman Arthur Schopenhauer very personally experienced sexuality as the humiliation of his supreme autonomy. (Safranski, 1991, p.137)

According to Schopenhauer the act of coitus takes us further down into an ego-less nature and makes of us the object of its action. In this way we become passive, and are thereafter 'driven' by our actions. As in Freud, we can see the sexual drive as an instinctual need to relieve tensions and move beyond the repressive nature of the unconscious. Schopenhauer writes,

The sexual impulse is proved to be the decided and strongest affirmation of life by the fact that for man in the natural state, as for the animal, it is his life's final end and highest goal. Self-preservation and maintenance are his first aim, and soon as he has provided for that, he aims only at the propagation of the race; as a merely natural being, he cannot aspire to anything more. (Schopenhauer, 1969, p.329)

In Ulysses repressive sexuality is depicted in both Leopold and Molly Bloom. The act of procreation is just that, an act, it carries no further significance or expression. We are driven by these sexual desires, and in turn are subject to them. After the untimely death of their son Rudy, Bloom and Molly never experience a successful coital relationship; eleven years elapse without a re-conjugation of their sexual relationship. Molly, of course, fulfills her sexual needs with the likes of Blazes Boylan, who cuckolds Bloom, reinforcing his own sexual longings and defeats. In Molly's closing monologue, for example, she muses about sexuality and is driven, so to speak, to strive after those very things she desires. In this manner Molly's sexuality is a driven or desire-based need to satisfy specific sexual ends. In Schopenhauer's 'disinterested' world, these strivings 
and desires are manifestations of a will-full humiliation; and as such, deprive us of autonomy. Schopenhauer depicts sex as interested, in that it draws us away from ourselves. If sex is a driven activity, then it has to be or have an object of desire or drive, which requires an act of will. In this manner there could be no disinterested sex; it is driven by an object or desire outside of us. In Joyce's Ulysses, sex would be a way out, a reprieve from disinterestedness. But as sexual needs or desires are seldom fulfilled, characters such as Bloom, and even Molly, are never given that reprieve. Sexual fulfillment, then, would be a way out, albeit fleetingly, from the cold dispassion of disinterestedness, the aloneness and solipsism of the Joycean character.

Schopenhauer suggests that the 'creative urge' is fundamental to all individuals: it is by way of inner thought, or disinterestedness, that man finds the creative clues to his existence. These 'creative urges' cannot be equated with biological or psychological strivings, but rather with aesthetics apprehension as understood in Schopenhauer's philosophical system. In Joyce's Ulysses this quest for inner solitude-the apprehension of ideas-culminates in Molly Bloom's soliloquy at the end of the novel. Molly Bloom extends herself beyond the rhetoric of the mundane, and into the creative language of existence itself. She occupies a domain of inner reality that is accomplished only through the inner strivings of a seamless inner thought, and in this manner discovers the true nature of herself. She achieves this by allowing her thoughts free-flow, and in doing so she is drawn away from the outside world and into her innermost thoughts. Molly soliloquizes at the end of Ulysses,

yes when I put the rose in my hair like the Andalusian girls used or shall I wear a red yes and how he kissed me under the Moorish wall and I thought well as well him as another and then I asked him with my eyes to ask again yes and then he asked me would I yes to say yes my mountain flower and first I put my arms 
around him yes and drew him down to me so he could feel my breasts all perfumed yes and his heart was going like mad and yes I said yes I will yes. (Joyce, 1992, p.933)

In Molly's ending monologue the reader is drawn into the interior of her thoughts, and given access to her innermost secrets. By doing so Joyce allows the reader to live vicariously through Molly's inner-thoughts and feelings.

As has already been suggested, the Schopenhauerian concept of 'disinterestedness' helps define the characters in Ulysses. In Joyce, this is undertaken with the utmost literary skill in the character of Molly Bloom. The overall creativity of Ulysses can be understood as an exercise in writing that maintains a close relationship with 'inner' processes and breaks the silence of thought that exists in each character's narrative. Following Schopenhauer's aesthetic, we might discover that Joyce's use of stream-of-consciousness and inner monologue are examples of a disinterested aesthetic that allows us access to the inner workings of each character's thoughts. Joyce's characters inhabit an inner monological narrative that is disinterestedly interested, allowing them to create a narrative of their own making, a disinterested interest. In doing so this opens up the notion of aesthetics as a will-less apprehension of ideas common both to Schopenhauer and Joyce. Schopenhauer, in relating will-lessness to the aesthetic, engineered a narrative philosophical voice of his own. As suggested, in Ulysses we are confronted with a picture of reality, or nature, that is created from the inner musings of each primary character; in Schopenhauer we find a conception of aesthetics that exists independent of the will itself; a disinterested narrative understanding of self. 
In Ulysses, inner thoughts, or monological narratives, give rise to a sense of the unknown, a sense of the goings-on in each character's mind; and perhaps also to a better understanding of our own inner worlds. Joyce used the idea of 'inner' monologue to add a disinterestedness to narrative; and in doing so created a work of such dense perspicuity that even today, eighty years after its publication, it continues to be an ambitious work. It is this preoccupation with 'disinterestedness' that extends the notion of 'inner thought' and creates the tragic aloneness that is to be found in Joyce's Ulysses.

Here is yet another example of Joyce's use of creative inner monologue to highlight the musings of the novel's main character Bloom.

From the sundial towards James's Gate walked Mr Kernan pleased with the order he had booked for Pulbrook Robertson boldly along James's street, past Shackleton's offices. Got round him all right. How do you do, Mr Crimmins? First rate, sir. I was afraid you might be in your other establishment in Pimlico. How are things going? Just keeping alive. Lovely weather we are having. Yes, indeed. Good for the country. Those farmers are always grumbling. I'll just take a thimbleful of your best gin, Mr Crimmins. (Joyce 1992, p.307)

We can see here the rich, textured language Joyce is renowned for and the creative energy that he expended on the simplest description. It is Bloom's narrative voice that extends the ground of creativity, and upon it builds an inner world of thought that entreats us to gaze through an open window at the private reflections of a sad and solipsistic mind. We are not audience to sense data or concepts here, but rather to emotions and feelings stripped naked of their material and conceptual conceits. Here Bloom is talking to himself about Kernan, whom he sees in the distance, then a short repartee with Mr. Crimmins over gin. Joyce's use of inner monologue gives us a better understanding of the nature of each character's private thoughts, and the creative 
disinterestedness that lies at its foundations. It is in his stream-of-consciousness narrative that we find disinterestedness, a pulling away from the outside, the interested, and a closing in on the inner or disinterested.

In the end, Bloom continues on his peregrinations through Dublin with the knowledge that his life will get no better no matter what he does. He is haunted by the death of his infant son and Molly's sexual flirtations, and sees no conclusion to his unhappiness. It is Bloom's sad and meaningless solipsism that truly underscores the terror and loneliness of the Joycean modern man. Molly, in concluding her scandalous soliloquy, falls back into a way of being in the world that demands nothing more of her than that she continue on as she always has; enclosed in a selfish and often unflattering otherness. In Schopenhauer's world both Molly and Bloom are so detached from the outside, the other of the world, that they are trapped, captive to their own inner thoughts. They are so disinterested, that the outside never seems to make its way into the inside, the inner. Both Molly and Bloom are disinterested from their own interestedness, so far removed from the outer that their inner words become a purgatory between inside and outside, interestedness and disinterestedness, disinterestedness and disinterest.

As illustrated, if we take Schopenhauer's notions of will-lessness and 'disinterestedness' and apply them to a reading of Joyce's Ulysses, we arrive at a disinterestedness common to both. In Joyce we come face to face with a rendering of the inner processes of thought whose creative invention is extraordinary, both for its use of language and narrative. The notions of disinterestedness, will-lessness and Schopenhauer's pessimistic notion of sexuality offer a reading of Ulysses that is desireless and direction-less; a world inhabited by partial-beings, who's attachment to the 
'outside' is always compromised. We see in the characters of Bloom, Stephen, and perhaps even Molly (though she may appear impassioned and sexualized in her inner thoughts, she still remains a prisoner to her own solipsism) a world of tragedy and loneliness that is similar to Schopenhauer's own philosophical pessimism. Perhaps, as Schopenhauer suggested, when the will is suspended from the mundane, on a plane where thought, imagination and intuition reign free, we will be capable of accessing a creative nature as yet unknown.

The notions of will-lessness and disinterestedness in both Schopenhauer's philosophy and Joyce's Ulysses invite us to look at the creative process and the creative artist with a new, albeit disinterested eye. Disinterestedness, and in keeping with Schopenhauer, will-lessness, are ways into creative thought, not detours out of it. In this manner Joyce's Ulysses can be read as a compelling example of how creativity can move beyond the veridical and mundane into the realm of a will-less and disinterested aesthetic apprehension. Schopenhauer's notion of disinterestedness, or a pulling away from the will, allows the artist to apprehend the ideal of the object or subject. This detachment from the outside, the drive or desire for or towards something, is what sets a disinterested aesthetic apart from a driven or willful one. Through stillness of thought, clarity of inner conviction, the artist is able to gain access to the thing in itself, the ideal or form of the subject or object. In Joyce's Ulysses, the characters exhibit just such disinterestedness; at times a disinterestedness of disinterest, that draws them deeper into the self and further away from the outside. Joyce created a day in the life of his characters that indulges their innermost thoughts, a disinterested narrative that captures the aloneness and solipsism of 
each. Whether Joyce himself wrote Ulysses from a disinterested aesthetic is another question, one that we will allow his characters to speak to.

Chapter Four, Freud and Joyce

What does Freud have to offer to an understanding of Joyce's Ulysses? We compare Joyce's use of stream-of-consciousness and inner narrative, and the principal character's yearning to realize instinctual desires that remain unfulfilled, with Freud's notion of free association, phantasy, childhood play, repression and the unconscious. Freud's analysand in free association with the analyst and Joyce's narrative technique and its relation to the reader have interesting similarities. The two start out as monological processes, the analysand's free association and Joyce's characters' inner narratives, and are then united and interpreted by a second party, the analyst and the reader of Ulysses.

Both Freud and Joyce used disconnected inner thought as a way to understand the unconscious and conscious processes in psychoanalysis and fictional narrative. In free association the analysand is basically free to think and speak about anything he/she wishes; everything that is said is viewed as a part of the bigger analytical picture. For example an individual might switch without logical connection from one subject to the other in the process of free association. Any bit of information is given some importance in relation to the whole and allowed to find a place in the analytical process. In Joyce's use of stream-of-consciousness the narrator is given free rein to speak about anything that comes to mind. It is this freedom of thought that allows the narrator to investigate the goings-on in his/her mind at any given moment. 
Freud introduced free association to psychoanalysis as a technique by which the unconscious could be accessed through the free expression of thought. By allowing the patient to freely express his or her thoughts, the unconscious would be allowed to seep to the top, thereby gaining access to consciousness.

Instead of urging the patient to say something upon some particular subject, I now asked him to abandon himself to a process of free association-that is, to say whatever came into his head while ceasing to give any conscious direction to his thoughts. It was essential, however, that he should bind himself to report literally everything that occurred to his self-perception and not to give way to critical objections which sought to put certain associations on one side on the ground that they were not sufficiently important or that they were irrelevant or that they were altogether meaningless. (Freud, 1990, V. 15, pp. 223-24)

In free association the analysand expresses whatever thoughts or images come to mind, not concerning him or herself with connecting the images or words into a structural whole. Freud felt that by listening to his patients freely associate, he could discover an underlying structure that may not be immediately apparent to the analysand. Certain word pairings, for example, or words and images that the analysand repeats without being consciously aware of them, all have a connection to the greater structural meaning.

In many ways, as I will show, Joyce's use of stream-of-consciousness--allowing his characters to freely express their innermost thoughts--shares similarities with Freudian free association. Molly Bloom's soliloquy at the end of Ulysses is a good example of Joyce's use of free-association taken to the extreme.

thyre all so different Boylan talking about the shape of my foot he noticed at once even before he was introduced when I was in the D B C with Poldy laughing and trying to listen I was waggling my foot we both ordered 2 teas and plain bread and butter I saw looking with his two old maids of sisters when I stood up and asked the girl where it was what do I care with it dropping out of me and that black closed breeches he made me buy takes you half an hour to let them down wetting all myself always with some brandnew fad every other week such a long one I did 
I forgot my suede gloves on the seat behind that I never got after some robber of a woman and he wanted me to put in the Irish Times lost in the ladies lavatory D B C Dame street finder return to Mrs Bloom... (Joyce, 1992, p.881)

Molly's ramblings seem nonsensical, a sort of schizoid word salad lacking in coherency and meaning. Joyce's use of stream-of-consciousness is found in Molly's speech as she thinks over the day and what has transpired in her thoughts. This is a wonderful example of stream-of-consciousness, one that allows us inside Molly's thoughts as she thinks them to herself. Joyce's masterful and ornate language adds a sense of the surreal to Molly's monologue, and examines the going-ons of her thoughts when they are not spoken but concealed.

Though Molly's ramblings may seem schizoid and incoherent, there is an inner consistency to them that is not readily available without a better historical understanding of her life. After one is reacquainted with Molly's past history and deepest desires, her ramblings seem to make more sense. They represent her emotive reactions to events in the past and how they are related to what she is thinking and feeling in the present, i.e. her subsequent afternoon sexual assignation with Blazes Boylan. In this manner her schizoid pattern of thought is less obtrusive and unavailable. Though Molly's ramblings seem like a questionable example of Freudian free association, they do give us an idea of what Joyce was trying to get at, the inner thoughts of his principal characters, and our inability to make sense of them without a clear history or understanding of Molly herself. As in psychoanalysis, a history of the analysand is needed to make sense of their wishes, desires, dreams and freely associated thoughts. 
Nabokov, in his essay on Joyce in Lectures on Literature, talks about Joyce's use of stream of consciousness in Molly Bloom's long soliloquy that concludes Ulysses,

First, the device is not more "realistic" or more "scientific" than any other. In fact if some of Molly's thoughts were described instead of all of them being recorded, their expression would strike one as more "realistic", more natural. The point is that stream of consciousness is a stylistic convention because obviously we do not think continuously in words-we think also in images; but the switch from words to images can be recorded in direct words only if description is eliminated as it is here. Another thing: some of our reflections come and go, others stay; they stop as it were, amorphous and sluggish, and it takes some time for the flowing thoughts and thoughtlets to run around those rocks of thought. (Nabokov, 1980, p.363)

In Ulysses we are drawn into a narration that is representative of the ongoing thoughts of the three main characters. Joyce uses an inner narrative or stream-ofconsciousness that grants the reader access to the principal character's inner thoughts. In his work on Ulysses called Fabulous Voyager, Kain writes,

The technique of the work has continued to preoccupy critics more than the interpretation of life that it affords. Actually, it is the most ambitious and monumental attempt in literature to render the inner lives of its three main characters-their thoughts, inhibitions, fears, and desires. Ulysses is, first of all, the greatest stream-of-consciousness novel in literature. (Kain, 1959, p.18)

Freudian free association allows the analysand to reach into the unconscious and retrieve memories and ideas that have lain dormant and repressed from childhood. In stream-of-consciousness Joyce lets the free-flow of narrative to permeate Ulysses. Repression works to inhibit the unconscious from finding purchase in consciousness. In free association the derivatives of what were initially repressed have free access to the conscious.

In carrying out the technique of psychoanalysis, we continually require the patient to produce such derivatives of the repressed as, in consequence either of their remoteness or of their distortion, can pass the censorship of the conscious. 
Indeed, the associations which we require him to give without being influenced by any conscious purposive idea and without any criticism, and from which we reconstitute a conscious translation of the repressed-these associations are nothing else than remote and distorted derivatives of this kind. (Freud, 1990, V.11 p.149)

Joyce's use of stream-of-consciousness narrative allows for the principal characters to access an inner narrative. In the process of stream-of-conscious a storehouse of unconscious imagery is accessed and invested in the character's narratives. Through the process of repression, censorship impedes the progress of unwanted imageries from gaining access to the conscious. Free association in analysis, and stream-of-conscious in writing, allow for the expression of these images in narrative, or as in Ulysses, inner narrative. These expressions, or effects as Freud calls them, can be found in free association and in stream-of-consciousness narrative. Through free association, as suggested earlier, the veil of repression is lifted, and formerly inhibited thoughts, memories and images make their way into consciousness. In Ulysses, Joyce's characters, as in Molly's soliloquy, achieve a similar process, allowing for seemingly disconnected thoughts and images to make their way into conscious thought. In the case of Molly, this appears as an almost incomprehensible mishmash of words, images, memories and reflections. As in analysis, the reader is left to establish patterns between these seemingly disparate parsing of words, phrases, memories, etc.

Is the narrative a derivative of the unconscious? What comes first? Does the process of writing create the stream-of-consciousness in the narrative, or does the narrative create the process of the unconscious? If we suppose that the writer gains access to the unconscious through free association, it would stand to reason that the unconscious was active before the narrative. However, if the unconscious is free- 
associated, then we might suppose that writing allows access to unconscious imagery, releasing formerly repressed imagery into consciousness. In order for a concept to be understood at all, it must first be accessed through language. In this manner an unconscious thought cannot find a hold in consciousness unless first represented in language. In analysis the interpretation of what is expressed allows the analysand access to the source of the repression. In Ulysses the characters' inner narratives find representation in the reader, who decodes or interprets the narratives.

The primary process can be linked to stream-of-consciousness thinking. These thoughts derived from the activity of free association and stream-of-consciousness are in themselves examples of an inner narrative present in the primary process. As we have seen in Freud's technique of free association, and in Joyce's use of stream-ofconsciousness, accessing unconscious or primary thinking is achieved through a free play or association of words and thoughts. These primitive, or primary images, thoughts, desires and wishes are what both Freud and Joyce are after, a seepage of the unconscious into conscious thought. Molly achieves this in her rambling soliloquy, and the Freudian analysand in free association. Joyce's unconscious primitive thoughts, though far less congruent, are nonetheless examples of primary process working it's way into secondary process.

In Joyce's Ulysses we are introduced to three narrative voices that lead us through their peregrinations through Dublin in one day. Their inner monologues capture the ongoing thought processes of each character. Leopold Bloom, the principal character in Ulysses, carries on a monologue in his head that extends the notion of free association and exemplifies stream-of-consciousness narrative. His thoughts are sometimes scattered 
and disjunctive, as he can be having both a conversation with another character and issuing comments and digressions on that conversation in his own mind. While at the apothecary Bloom's thoughts wander as he listens to the chemist,

Peau d' Espagne. That orangeflower. Pure curd soap. Water is so fresh. Nice smell these soaps have. Time to get a bath round the corner. Hammam. Turkish. Massage. Dirt gets rolled up in your navel. Nicer if a nice girl did it. Also I think I. Yes I. Do it in the bath. Curious longing I. Water to water. Combine business with pleasure. Pity no time for massage. Fell fresh then all day. Funeral be rather glum. (Joyce, 1992, p.105)

He is thinking of the day ahead and the funeral he is to attend later that day. Such inner narrative is common to Joyce's characters, a seemingly disconnected play of words that has an inner meaning for each character.

Freud's use of free association to uncover the thought processes in the analysand is very much like Bloom's inner monologue, as they are both derivatives of unconscious imagery rendered conscious. It might be contended that free association and stream-ofconsciousness represent an inner monologue, or the unfolding of a story, in the mind of the analysand or fictional character. Free association and stream-of-consciousness require an interpreter, the analyst or the reader, to make sense of the meaning in the narrative. In the analytic situation the best interpretation is the one that has the most positive or therapeutic impact on the analysand. In a narrative such as Bloom's the same could be said, as it permits him to make sense of his current situation, even if it appears senseless to the reader. In analysis it is the analyst's job to interpret and find meaning in the analysand's free associative thoughts. By drawing attention to connections between seemingly disconnected thoughts or images, the analysts helps the analysand establish meaning in his or her thoughts. In reading a novel such as Joyce's Ulysses, the same is true of the reader, whose interpretation establishes connections between disconnected 
thoughts and stream-of-consciousness narrative. Both the analyst and the reader often see patterns and connections, the analyst in the analysand's thoughts, and the reader in the character's narrative.

Free association complements stream-of-consciousness narrative in that they both disclose a 'primary' thought process. When an analysand free-associates he/she might be said to be accessing a stream-of-consciousness narrative that allows him/her to remember and retrieve thoughts and images that at one time were repressed, and for the most part unconscious. In free association the analysand does not engage in a dialogue with the analyst, the process remains a solitary one of retrieval and construction. By this I suggest that free association and stream-of-consciousness are solitary activities. They are not dialogical but singular. The analyst's interpretation is overlain on the associations and connections suggested, and sometimes false or negative imagery revealed. In both Freud and Joyce this inner thought or narrative is solitary until a second party, the analyst in Freud and the reader in Joyce, are introduced to form a dialogue or union between the two. The analyst's interpretation and the working through of the analysand, and Joyce's characters' inner narratives or stream-of-consciousness as interpreted by the reader of Ulysses, form this union. The two seemingly unconnected processes have similar outcomes and functions.

Joyce's novel Ulysses was a response to Modernism: it changed what we understood as narrative, and in it's place built a structure of language that introduced the notion of 'inner thought'. This inner thought process, exemplified by Joyce's use of stream-of-consciousness as a narrative process, revolutionized the idea of the novel. In Freudian psychoanalysis, much like Joyce's stream-of-consciousness, the narrator is a 
character (or, characters) who expose his/her inner thought processes by allowing the free-play of thought and interplay of disjunctive ideas. These inner workings of thought are not always linear or structural in the grammatical sense; they are composites of thought that may or may not be syntactically correct. It is this disconnected process of free association that enables the analysand to gain access to the unconscious. In literature this access is found in the use of stream-of-consciousness. In Re: Joyce'n Beckett, Steven Connor writes of Joyce,

For the surrealist, the artist needed to escape from the constraints of logic and rationality not in order merely to destroy them but in order to reconstitute their authority at a different level, the level of dream, symbol, or the unconscious. For Andre Breton in particular, the dissolution of conscious control was intended to allow the authority of the Freudian unconscious to assert itself. And what is described repeatedly in surrealistic writings is the way in which the loosening of one kind of power, the power of reason, by the foregrounding of randomness or change, actually brings to light a more profound unity of design in a work of art. (Carey \& Jewinski, 1992, p.148)

It is this randomness of inner thought that gives free association and stream-ofconsciousness their singular subjectivity.

There is a scene in Ulysses where three of the characters Stephen Dedalus, Lynch, and Bloom enter a brothel in Dublin. In this scene we are met again with the unconscious activities of the three narrative minds in thought. Kain writes,

Remarkably skilful is the technique of this scene. Just as in the past we have had human aspiration submerged by the traffic and confusion of the external environment, now it is menaced from within by the seething desires of the libido itself. In a lurid midnight atmosphere, with the underside of civilization revealing itself in slum and brothel, fumes of intoxication release the hidden fears and desires of Stephen and Bloom. The style-that of expressionistic drama-merges the characters, their dreams, and the setting in a phantasmagoria of weird shapes, sounds and voices. Possibly the most brilliant dramatization of Freudian psychology in literature, this chapter indicates a turning-inside-out of the point of view usual in the stream-of-consciousness technique, for, instead of the individual's remaining in the foreground accompanied by his many subconscious 
musings, here the hidden fears and desires become dramatized, as in dreams, and the individual fades into the background. (Kain, 1959, p.31)

These stream-of-consciousness musings are fuelled by the unconscious, and fed by the same activities that come to the fore in free association. Free association and stream-of-consciousness are processes that go behind and beyond the present, accessing the deepest recesses of the unconscious. In this way the stream-ofconsciousness or inner narratives of Joyce's characters are similar to the free association of the analysand in psychoanalysis. Joyce's characters are captive to their inner thoughts, hostage to an unconscious process that at times appears senseless. However strange and muddled these thoughts appear, they have meaning for each character. Through the inner narrative of his principal characters, Joyce allows us a glimpse into this seemingly disorderly pattern of thinking. Much like the analyst, the reader is left to make sense and interpret what is expressed in the character's inner narratives.

In the "Circe" episode in Ulysses practically all of the characters met earlier in the day, and all their musings, thoughts, dreams and ideas, come together to form an incredible dream.

He implored me to soil his letter in an unspeakable manner, to chastise him as he richly deserves, to bestride and ride him, to give him a most vicious horsewhipping. MRS BELLINGHAM: Me too. (Several highly respectable Dublin ladies hold up improper letters received from Bloom)

THE HONOURABLE MRS MERVYN TALBOYS: (Stamps her jingling spurs in a sudden paroxysm of sudden fury) I will, by God above me. I'll scourge the pigeonlivered cur as long as I can stand over him. I'll flay him alive.

BLOOM: (His eyes closing, quails expectantly) Here? (He squirms) Again! (He pants cringing) I love the danger. (Joyce, 1992, p.593)

The surrealism of the "Circe" episode seems to explode onto the page; a hodgepodge of narrative voices matched one against another, forming an almost fugal cacophony. Kain 
writes,

Psychologically, it is one of the most ambitious attempts in literature to render the world of the subconscious, the seething mass of memory, desire, and frustration elucidated by Freud. (Ibid.p.141)

Again we can see the similarities between the Freudian free association and Joycean stream-of-consciousness, even though Joyce's characters seem defeated with meaninglessness.

In free association the analysand reaches back into the relative confusion of the unconscious, seeking to interpret clues to present behaviour. Often the day's residuals are explored and associated with other events, feelings and memories that impact behaviour. Freud believed that fantasy played a principal role in creative activity: he considered fantasies to be important clues to the instinctual wishes and strivings, reaching as far back as childhood. These fantasies play an important role in the construction of dreams and desires. Freud said,

Art brings about reconciliation between the principles in a peculiar way. An artist is originally a man who turns away from reality because he cannot come to terms with the renunciation of instinctual satisfaction which it at first demands, and who allows his erotic and ambitious wishes full play in the life of phantasy. He finds a way back to reality, however, from this world of phantasy by making use of special gifts to mould his phantasies into truths of a new kind, which are valued by men as precious reflections of reality. Thus in a certain fashion, he actually becomes the hero, the king, the creator, or the favorite he desire to be, without following the long roundabout path of making alterations in the external world. But he can only achieve this because other men feel the same dissatisfaction as he does with the renunciation demanded by reality, and because that dissatisfaction, which results from the replacement of the pleasure principle by the reality principle, is itself a part of reality. (Freud, 1990, V.12, p.224)

The interplay of fantasy in stream-of-consciousness is apparent: it is shown in the manner in which Joyce uses the unconscious inner narrative to reveal the wishes, desires and primitive thoughts that are the subject matter of psychoanalytic theory. Joyce allows 
his characters a certain leeway in expressing their deepest and most profound thoughts through inner narrative. Through these narratives the characters reach a deeper understanding of their primitive desires and wishes. The characters find themselves using stream-of-consciousness to access forbidden desires or instinctual demands. In this manner they can be said to be 'free associating' in the way that the analysand is freeassociating in the analytic session.

Freudian themes (repressed childhood wishes, unconscious desires, displacement and sublimation) work to create a picture of Dublin society. In this way Ulysses can be compared to a psychoanalytic journey through the vicissitudes and illusions of its three main characters. In Ulysses, we are never quite sure that what we are reading is a conscious or an unconscious expression of wishes and desires. This inner narrative is similar to the Freudian notion of the unconscious and free association, as both invite an interpretive disclosing of meaning.

The inner narratives of Joyce's characters can be seen as examples of unconscious images and memories from childhood and residuals of the previous day or days. With respect to childhood memories Freud writes,

What someone thinks he remembers from his childhood is not a matter of indifference; as a rule the residual memories-which he himself does not understand-cloak priceless pieces of evidence about the most important features in his mental development. (Ibid. p.175)

The main character in Ulysses, Bloom, has few positive or satisfying thoughts. It is this disinterestedness that runs through most of the narrative in Ulysses: the search for a better life or Bloom's yearning for his deceased son Rudy. If we are to paint Joyce's narrative with a Freudian brush, we will no doubt discovery that the whole of Ulysses is 
an instinctual wish for better things to come. But Joyce's characters seem completely disinterested even in themselves, experiencing life as an endless drudgery without a moment's reprieve. Nothing, or very little, seems to matter to them, they simple trudge through the day in a dark fugue, one foot thrown in front of the other. Bloom's inner narrative best exemplifies this, and his almost forlorn attitude towards fate and the drudgery of his life. Freud's notions of dissatisfaction and the demands of reality are ever present in Ulysses, as each character struggles to find his/her way through the labyrinth of their innermost thoughts. Kain suggests that Joyce, much like Freud, recognized this ongoing struggle, and gave voice to it in the characters in Ulysses.

Freud's Interpretation of Dreams offers some insight into Joyce's use of language and metaphor. Ulysses is teeming with examples of double-speak and slips of the tongue. He used uncommon spellings of common words and was known to do away with punctuation altogether, as is evident in Molly's soliloquy at the closing of the novel. Freudian analysis and dream interpretations are present in Joyce's work; they combine to create a world picture of Dublin society that was looked upon as being both scandalous and pornographic. By freeing his characters from the social and religious mores of Irish society, Joyce allowed his scandalous and somewhat pornographic side unfettered reign. This is possible, as we have seen, in unconscious and inner narrative and Freudian dream interpretation. Ricouer writes,

Passing from night dreams to daydreams, form daydreams to play and humor, then to folklore and legends, and finally to works of art, he [Freud] attests, by this species of increasingly closer analogy, that all creativity is involved in the same economic function and brings about the same substitution of satisfaction as the compromise formations of dreams and the neuroses. (Ricouer, 1970, p.520) 
Joyce's interpretations of his wife Nora's dreams show his interest in dream interpretation. Even though he may not have accepted a Freudian analysis of dreams, it can be conjectured that he did have some interest in psychological interpretation as represented in Freud's work. Ellmann points this out in his biography of Joyce,

He did not tell Budgen of a dream book he kept in 1916, in which he noted down Nora's dreams with his own interpretations:

Shakespeare is present

There are two ghosts in the play.

Fear that Lucia may be frightened.

Interpretation: I am perhaps behind this dream. The 'new discovery' is related to my theory of the ghost in Hamlet and the public sensation is related to a possible publication of that theory or my own play* The figure of Shakespeare present in Elizabethan dress is a suggestion of fame, his certainly (it is the tercentenary of is death) mine not so certainly. The fear for Lucia (herself little) is fear that either subsequent honours or the future development of my mind or art or its extravagant excursions into forbidden territory may bring unrest into her life. (Ellmann, 1982, pp. 436-7)

As discussed in the chapter on Freud, dreams are often the source of creative energy. The images and hidden wishes represented in the dreamscape offer a wellspring of creative ideas. This is most evident in Joyce's dream of Nora, and his interpretation of the hidden meaning in the manifest dream imagery. The dream imagery in the "Circe" episode in Ulysses, as demonstrated in the preceding quote, shows how Joyce used the notion of dreams and dream content to describe his characters' inner thoughts. Even though the narratives may not appear to represent dreams or dream work, they do add an ethereal quality to the characters' narrative voices. The narratives often appear as daydreams or a detachment from reality, a way for each character to find refuge from the confusion and dissatisfaction that surrounds them. 
Many artists create a reality or world picture that represents subjectivity of imagination and creativity. The work of art need not be a representation of some one reality; but rather an interpretation or representation of a reality as seen through the eyes of the artist. It is this Freudian primary process that takes advantage of the re-imagining, and in doing so utilizes the imagination and intuition of the artist to create a representation of a perceived reality that describes the 'inner' workings of the artist's mind. These inner workings of thought are found throughout Ulysses in Joyce's manipulation of stream-of-consciousness and inner narration.

The primary process as underlined in Freud's work on the ego and psychopathology, and in Joyce's use of the 'inner' monologue as a narrative tool in Ulysses, are both examples of the differing hypothesis of inner processes. Stream-ofconsciousness and free association are examples of such an inner process. They are freely given over to hallucinations and the interplay between reality and phantasy. As many works of art are the result of hallucinations and dreams, we cannot, as discussed earlier, rely on the common usage of rationality as a means to a better understanding of these processes. Freud believed that infants were originally dominated by the pleasure principle, the need to avoid pain and obtain pleasure. Freud writes,

The growing child, when he stops playing, gives up nothing but the link with real objects; instead of playing, he now phantasises. He builds castles in the air and creates what we called daydreams. (Ibid. p.146)

In Joyce's Ulysses these castles in the air take on the form of hidden or inner narration's allowing for the writer to explore long repressed phantasies instinctual wishes.

The creative writer, much like the child at play, finds some satisfaction in discovering the inner sources of these instinctual desires and needs. In Joyce's Ulysses, 
these inner needs and desires are represented in the narration of its main characters. Through their search for meaning and purpose to life, and in some sense contrition, they explore the attitudes and principles of the characters they encounter throughout the day, and their own relationship to the world. Contrition in that the principal characters search for absolution for past wrongdoings and even in anticipation for those yet to happen. This is no better illustrated than in Bloom's reminiscing about his dead son, Rudy, and the guilt and sorrow that Stephen Dedalus experiences over the untimely death of his mother.

Her gazing eyes, staring out of death, to shake and bend my soul. On me alone. The ghostcandle to light her agony. Ghostly light on her tortured face. Her hoarse loud breath rattling in horror, while all prayed on their knees. Her eyes on me to strike me down. (Joyce, 1992, pp.10-11)

Freud's writings on creativity in his work 'Creative Writers and Daydreaming' offer the reader of Ulysses interesting insights into Joyce's characters. The function of the primary process in thinking and childhood play, and how this is often carried over into adulthood, the place of unconscious wishes and primitive thinking in the construction of works of art and literature. The use of free association to reach into the unconscious, releasing formerly repressed thoughts, memories and images. How the reader, like the analyst, is an interpreter, finding patterns and connections in the characters' thoughts and inner narratives in a work of fiction. How dreams can be the source of creative ideas, and how each character has his or her often-solitary inner life, one that we are left to interpret and decode.

When one reads a novel such as Joyce's Ulysses, one can't help but see it through a Freudian lens, the use of stream-of-consciousness narrative, the characters' dissatisfaction with the everydayness of life, their need to escape from the drudgery of existence into an inner world of their own making. Joyce's characters live in an inner 
world, one of loneliness and suffering, never quite finding their way back into the light of day, but simply continuing to trudge through the darkness of their inner thoughts. Their lives' are governed by the primary process, a primitiveness, an almost disinterest in their own interest. Freud drew our attention to the need to express ourselves, our innermost desires, needs and hidden thoughts. The creative artist, the writer, the poet and the musician express this need through their creative work, the creation of fictional realities. Joyce did just that in Ulysses, creating a fictional world inhabited with a cast of characters who allow us to look inside their thoughts, their innermost desires, failures, wishes, fears and detachment from the world and themselves.

Joyce's inner narrative and Freud's free association allow us an insider's glimpse of the solitariness of thought, the hidden beneath the unconcealed, the self-disgusted and aloneness behind the seemingly disconnected inner narrative. Freud's notion of creativity encourages a reading of Joyce's Ulysses that underlines the notion that our innermost thoughts and desires, our sadness over wishes never to be fulfilled, fuel our need to create competing realities, ones that compensate for this inner solitariness. Joyce's Ulysses is a tribute to the solipsistic narrative voice that trudges through a life never quite lived, recreating a life, a past and a future, that is bearable, if only for a moment. Freud's work on creativity although modest, offers us the opportunity to reinterpret and recreate our lives with renewed hope, and if not hope, than a process by which that hope can be retrieved. Joyce's Ulysses shows us how our inner narratives mould our self-concepts, and just how depressing and pathetic those selves can be when we live in an inner process where hope is non-renewable. 


\section{Conclusion}

Joyce, Freud and Schopenhauer each made their own impact on literature, psychology and philosophy. A closer look, however, opens up a new and exciting vista from which to view, and read, these three great men. Joyce's Ulysses is a book that has been the topic of much scorn, misunderstanding and jubilation. The almost assonant style of the text is troublesome for many, and a welcome challenge to others, those with the patience and wherewithal to read it to the end. With its non-linear plot, narrative undershadowing and lack of proper grammar and syntax, it represents a shift away from modernism to a postmodern style of writing. Joyce's Ulysses draws one into the strange monological world of Dublin at the turn of the century, a city teeming with eccentric characters and a cacophony of equally strange narrative voices. Ulysses broke the rules, and having done so, left an indelible imprint on twentieth century literature.

Schopenhauer created a philosophical world where the 'will' and the sensual reigned supreme. His influence, indeed, is immense. Schopenhauer's notion of a 'disinterested' philosophical agent, and a 'world as will and representation', not only influenced Freud (see Andrew Brook's essay on Freud and Schopenhauer), but the way we see and experience ourselves in the world.

Freud's legacy cannot be dispensed with lightly, as his work on the unconscious, neurosis and his 'talking cure', are still part of the canon of psychology, albeit one that is getting smaller as neurological and pharmacological psychology rush to the fore. The notion that the unconscious speaks through behaviours and symptoms, both neurotic and everyday, helped change the way we approach our feelings, actions and forgotten 
memories. The French school of surrealism lead by Andre Breton, acknowledged Freud's impact on the free-play of language, thought and creativity. Their use of 'automatic writing' and 'stream of consciousness' are but two examples of Freud's influence on writing and creative work.

Schopenhauer's notion of a disinterestedness and Joyce's use of mono-logic narrative voices seem to have a relation to one another, a stepping back, as it were, from the everyday and mundane, allowing for a unique vision and apprehension of reality, and the everydayness of the world. Schopenhauer's 'will-lessness' and Joyce's 'stream of consciousness' admit for an engagement and apprehension of the world, and our place in it, that is both frightening and intriguing. Frightening in its solipsism, and intriguing in its imaginative possibilities. Joyce's use of monological narrative voices and non-linear plotting are examples of this way of apprehending and engaging in the world.

Freud's notions of sublimation, displacement, dreaming and dream-work can be 'read into' Joyce's Ulysses if we allow ourselves a wide berth and unlimited imagination. Creativity is neither principally a conscious or unconscious activity, but rather a concomitance of the two. Joyce's Ulysses is such a work, a concomitance of the two, an opening up to the possibilities of creative imagination. We, the reader, bring the creativity to the text, our own meanings, thoughts, memories, ideas and past experiences, all served up on the text and narrative of Ulysses. In this way creativity is brought to something, not derived from it. True, the artist brings his or her creativity and imagination to a work of art or text, but it's up to us, the reader or viewer, to ultimately give it its creative feel. 
Schopenhauer, Freud and Joyce are examples of such creativity, as they brought their imaginations, ideas, thoughts and creativity to whatever they created. The disinterested agent, the monological narrative voice, the unconscious, or a concomitance of the three, influence, and ultimately impact creativity, and Joyce's monolithic Ulysses is a fine illustration of what can be achieved when all three are put into service.

\section{Works Cited}

Brook, Andrew and Young, Christopher. Schopenhauer and Freud. New York: International Journal of Psychoanalysis, Vol. 75, 1994

Carey, Phyllis, Jewinski, eds. Re: Joyce'N Beckett. New York: Fordham University Press, 1992.

Csikszentmihalyi, Mihaly. Creativity. New York: Harper Collins, 1996.

Einstein, Albert. Ideas and Opinions, transl. Sonja Bargman. New York, Three Rivers Press, 1954.

Elliot, Anthony, ed. Freud 2000. New York: Routledge, 1999.

Ellmann, Richard. James Joyce. Oxford: Oxford University Press, 1982.

Fonagy, Peter. On Freud's “Creative Writers and day-dreaming”. New Haven: Yale University Press, 1995.

Freud, Sigmund. The Penguin Freud Library, 15 vols. London: Penguin Books, 1990.

Gardiner, Patrick. Schopenhauer. Middlesex: Penguin Books, 1963.

Gay, Volney P. Freud on Sublimation, Reconsiderations. New York: State University of New York, 1992.

Infante. On Freud's “Creative Writers and day-dreaming”. New Haven: Yale University Press, 1995.

Janaway, Christopher. Schopenhauer. New York: Oxford, 1994. 
Joyce, James. Ulysses. London: Penguin Books, 1992.

Joyce, James. The Critical Writings, Mason, Ellsworth and Ellmann, Richard, eds. New York: Cornell University Press, 1989.

Kain, Richard M. Fabulous Voyager. New York: The Viking Press, 1959.

Lemlij. On Freud's “Creative Writers and day-dreaming”. New Haven: Yale University Press, 1995.

Levine, Michael, P. ed. The Analytic Freud, New York: Routledge, 2000.

Lewis, Wyndham. Time and Western Man. Boston: Beacon Press, 1957.

Nabokov, Vladimir. Lectures on Literature. New York: Harcourt Brace Jovanovich, 1980

Power, Arthur. Conversations with Joyce. London: Millington, 1974.

Ricoeur, Paul. Freud and Philosophy: An essay On Interpretation. New Haven: Yale University Press, 1970.

Robb, Peter. The Man Who Became Caravaggio. New York: Picador, 1999.

Rycroft, Charles. Dictionary Of Psychoanalysis. London: Penguin Books, 1995.

Safranski, Rudiger. Schopenhauer And The Wild Years Of Philosophy. Cambridge: Harvard University Press, 1991.

Schopenhauer, Arthur. The World as Will and Representation, 2 vols. New York: Dover, 1969 \& 1966.

Schopenhauer, Arthur. Essays and Aphorisms. London: Penguin Books, 1970.

Spector Ethel, Person, Fonagy, Peter, Figueira, Servulo Augusto eds. On Freud's "Creative Writers and day-dreaming". New Haven: Yale University Press, 1995.

Sulloway, Frank J. Freud, Biologist of the Mind. Cambridge: Harvard University Press, 1992. 